\title{
Assessment of the observability of coastal currents in LRM and SAR altimetry observations: a north-western Mediterranean Sea case study
}

\author{
Alice Carret $^{1,2}$, Florence Birol ${ }^{1}$, Claude Estournel ${ }^{1}$, Bruno Zakardjian $^{3}$ \\ 5 'LEGOS,Université de Toulouse-CNES-CNRS-IRD, OMP, 14 Av. E. Belin, 31400 Toulouse, \\ France \\ ${ }^{2}$ SERCO, Via Sciadonna 24-26, Frascati, Rome, Italy \\ ${ }^{3}$ Université de Toulon, CNRS/INSU, IRD, Mediterranean Institute of Oceanography (MIO), \\ UM 110, 83957 La Garde, France
}

10 Correspondence to: Alice Carret : alice.carret@legos.obs-mip.fr

\begin{abstract}
Over the last three decades, satellite altimetry has observed Sea Surface Height variations, providing a regular monitoring of the ocean circulation. Altimetry measurements have an intrinsic signal-to-noise ratio that strongly limits the space scales, and then the geophysical information that can be captured with this instrument. However, the recent progress made on both altimetry sensors and data processing, offers new perspectives in terms of researchoriented and operational applications. In this paper we present a methodological study that helps to better quantify the impact of this progress in terms of coastal circulation.
\end{abstract}

20 We focus on a case study: the Northern Current, a narrow slope current (less than $60 \mathrm{~km}$ wide) located in the North Western Mediterranean Sea. We first use a high resolution numerical model validated with HF radars and underwater glider data to define the general characteristics of the Northern Current in terms of surface velocity and sea surface height signature. These characteristics are then compared with corresponding estimates of sea

25 surface height velocity derived from $1-\mathrm{Hz}$ altimetry data sets from three missions: Jason 2 (Ku-band LRM), SARAL (Ka-band LRM) and Sentinel-3A (SAR). The data from all missions were processed with the coastal-specific X-TRACK strategy.

We show that near Toulon, the model is very close to the observations in terms of current estimates, providing a very good reference for altimetry data located in this area. The

30 Northern Current is observed $15 \mathrm{~km}$ to the coast on average, with a mean core velocity of $0.44 \mathrm{~m} \mathrm{~s}^{-1}$. Its signature in sea level consists of a drop whose mean value at $6.14^{\circ} \mathrm{E}$ is $6.9+/-$ $2.2 \mathrm{~cm}$ extending over $18+/-4 \mathrm{~km}$. These variations show a clear seasonal pattern, but high frequency signals are also present most of the time. In 1-Hz altimetry data, the mean sea level 
drop associated with the Northern Current is overestimated by $3.6 \mathrm{~cm}$ for Jason 2, $0.3 \mathrm{~cm}$ for

SARAL and $1.4 \mathrm{~cm}$ for Sentinel-3A. In terms of corresponding sea level variability, Jason 2 and SARAL altimetry estimates are larger than the model reference $(+1.3 \mathrm{~cm}$ and $+1 \mathrm{~cm}$, respectively) whereas Sentinel-3A shows closer values $(-0.4 \mathrm{~cm})$. Without any sea level data filtering, the standard deviation of altimetry-derived velocity values is 3.7, 2.4 and 2.9 times too large for Jason-2, SARAL and Sentinel-3A, respectively. When filtering sea level data, the distribution of altimetry velocities tends to converge towards the model reference with a $50-\mathrm{km}, 30-\mathrm{km}$ and $40-\mathrm{km}$ cutoff wavelength for Jason-2, SARAL and Sentinel-3A data, respectively.

\section{Introduction}

45 Since the beginning of the $90 \mathrm{~s}$, satellite altimetry has enabled many regional circulation studies (e.g. Troupin et al., 2015; Vignudelli et al., 2000 in the NW Mediterranean Sea; Gourdeau et al., 2017 in the Solomon Sea; Liu et al., 2018 in the South China Sea, ...). Its main advantages are its long-term and regular temporal coverage and its synoptic character. Large scale structures $(>150 \mathrm{~km})$ are well captured with this observational technique which

50 has a crucial role in the knowledge of the circulation at global scale (Fu and Le Traon, 2006). On the contrary, meso-scale and sub-meso-scale processes such as eddies and meanders or narrow coastal currents are historically poorly resolved by altimetry and generally documented by in situ observations or numerical models (e.g. for the NW Mediterranean Sea: Casella et al., 2011; Guihou et al. 2013; Juza et al., 2013; Ourmières et al., 2010; Schroeder et 55 al., 2011). However, during past years, new altimetry techniques such as the Ka-band frequency and the SAR (Synthetic Aperture Radar) mode, as well as progress in data treatment, have led to a significantly gain in observability of fine scale ocean structures in general and of coastal features in particular (Birol et al., 2021; Morrow et al., 2017; Verron et al., 2018).

60

Despite the progress made, intercomparisons with in situ observations of near-coastal currents have shown that the corresponding altimetry-derived surface velocities are underestimated (Birol et al., 2010; Jebri et al., 2016). In Carret et al. (2019), using long time series of both ADCP and glider data as a reference for the Northern Current (NC hereinafter) velocities, we have shown that satellite altimetry data underestimate the amplitude of NC seasonal variations by $\sim 40-45 \%$. This can be explained by the ageostrophic current component, not captured by altimetry, but also by the effective data resolution, which is limited by the altimeter noise and coastal data processing issues, resulting in near-shore data gaps. The impact on signal observability varies from one altimeter instrument to another,

70 decreasing with new radar techniques and data processing approaches (Birol et al., 2021; Morrow et al., 2017). Nevertheless, there is still a need to specify more precisely the improvements in coastal observability related to differences in altimetry technologies (Ka- 
band, SAR altimetry) and processing techniques. In order to optimize the use of altimetry in near-shore areas and to finally define its place among other coastal observation systems, it is important to better study the dynamic processes that can be observed and to quantify the associated accuracy.

As satellite altimetry measures sea surface height (SSH or sea level hereinafter), the observability condition is that the processes of interest have a sea level signature and spatiotemporal scales larger than the altimetry resolution. Over the open ocean, the altimetric observability problem is generally studied through a spectral approach (Dufau et al., 2016; Morrow et al., 2017; Vergara et al. 2019). This gives a mean statistical solution over the considered region, but can not be used in the coastal ocean where too short satellite track sections often impede the computation of a spatial spectral analysis. Several studies (Bouffard et al., 2008; Carret et al., 2019; Pascual et al., 2015; Troupin et al., 2015) have used in situ observations to analyze the resolution capability of coastal altimetry data but they came up against the scarcity of independent measurements and their non-colocation in space and/or time.

90 In this paper, we propose a different strategy based on a high resolution numerical model. Our purpose is to quantitatively analyze if a particular coastal dynamical structure can be observed with satellite altimetry. Using a high resolution model may help to overcome the issue of colocation between in situ and altimetry, but given the essential condition that the physical process studied must be correctly represented by the model. After a careful model validation step in the study region, our approach will consist in using the model to quantify the SSH signature of an identified physical process along a particular satellite track. In a second time, the 3 model solution will be considered as the reference and compared with the SSH signature captured in the altimetry dataset along the considered tracks. The observed differences will be analyzed and quantified through different diagnostics.

The case study chosen is again the NC in the Western Mediterranean Sea (NWMed hereinafter). This region is considered as a laboratory area for coastal altimetry studies (Birol et al., 2010; Birol and Delebecque, 2014; Bouffard et al., 2008) because of its small Rossby

105 radius (around $10 \mathrm{~km}$, Grilli and Pinardi, 1998) leading to a wide variety of mesoscale and submesoscale structures. We can also benefit from the variety of in situ data collected from the MOOSE (Mediterranean Ocean Observing System for the Environment, https://www.moose-network.fr/) integrated observing system and of the long experience and really good performances previously obtained with the high resolution SYMPHONIE

110 numerical model in the study area (Damien et al., 2017; Estournel et al., 2016; Herrmann et al., 2008).

The NC is a narrow slope current (Fig. 1) formed by the junction of the Eastern (ECC) and 
Western (WCC) Corsica Currents in the Ligurian Sea (Taupier-Letage and Millot, 1986). It seasonal component with a maximal transport (1.5-2 Sv, Alberola et al., 1995) and increased mesoscale variability in winter (e.g. Crépon et al. 1982; Flexas et al. 2002; Sammari et al. 1995). Its position relative to the coast also varies through the year, from less than $20 \mathrm{~km}$ to about $30 \mathrm{~km}$ from the coast (Niewiadomska, 2008; Sammari et al., 1995), as well as its depth (more than $200 \mathrm{~m}$ in winter and 150-200 $\mathrm{m}$ during the rest of the year) and width (30 km with a narrowing in winter, Alberola et al., 1995).

In the past, the $\mathrm{NC}$ variability has been intensively studied with in situ observations and models: mesoscale fluctuations in Sammari et al. (1995); eddies associated in Casella et al. (2011), Hu et al. (2011) and Schaeffer et al. (2011). Birol et al. (2010) have highlighted the contribution of along-track satellite altimetry to study the NC variability. Since then, other studies have used such data to investigate the $\mathrm{NC}$ circulation as well as the recirculation and associated meanders (Borrionne et al., 2019; Morrow et al., 2017; Pascual et al., 2015).

130 Here, we will investigate in details the NC observability issue for three altimetry missions associated to different techniques: Jason 2, with the classical Ku-band LRM nadir altimeter, SARAL which uses the Ka-band frequency in LRM mode and Sentinel-3A (Sentinel-3 hereinafter) with its Synthetic Aperture Radar mode. Section 2 describes the study tools and the model validation step. Section 3 presents the methodology used to quantify the NC sea level signature in the Ligurian Sea and the results obtained. Section 4 focuses on the NC observation with the three altimetry missions and analyzes the differences obtained between altimetry and the model. Section 5 summarizes and concludes the paper.

\section{Study tools}

In this study, in situ (glider) and HF radar data are first used to validate a regional numerical simulation (section 2.3). Our study period, strongly constrained by both the in situ data and model simulation availability, goes from 2011 to 2019.

\subsection{Data}

\section{1.a) HF radars}

We took advantage of the 2 years of data, from May 2012 to September 2014, provided by the HF Wellen radar (WERA) instruments installed near Toulon as part of the MOOSE network (Zakardjian and Quentin, 2018). It corresponds to the dataset available at the time of the study. The stations are located in Cap Sicié and Cap Bénat-Porquerolles in respectively monostatic and bistatic eight-antenna configurations (now upgraded to twelve antenas by site, 
Dumas et al., 2020). Their positions enable to monitor the NC upstream the Gulf of Lions (Fig. 2a) and the mesoscale dynamics that occur in this region of cross-shelf exchanges and strong atmospheric forcing (Mistral, Tramontane winds). They operate at $16 \mathrm{MHz}$ with a 50 $\mathrm{kHz}$ bandwidth, resulting in a spatial resolution of $3 \mathrm{~km}$, and allow an angular resolution of $2^{\circ}$. The radars provide the surface current every hour over a region of $60 \times 40 \mathrm{~km}$. Data are then filtered from tides and inertial oscillations, edited and averaged daily and finally bined on a regular $2 \times 2 \mathrm{~km}$ grid.

\section{1.b) Gliders}

160 In the NWMed, a number of gliders have been deployed since 2005 along different transects, measuring temperature and salinity vertical profiles. We focus on a regular line, from Nice to Calvi where 36 deployments occurred from 2009 to 2016, as part of the MOOSE network. From 2011 to 2017, there are 204 sections (ascending or descending). Data were treated according to Carret et al. (2019) who discarded profiles being too short or deviating too much from an average Nice-Calvi trajectory. It results in temperature and salinity data down to $500 \mathrm{~m}$ (depth reached by all gliders), gridded with a $4 \mathrm{~km}$ horizontal bin size along the mean trajectory considered as a reference track. The temperature and salinity data are then filtered using a $15 \mathrm{~km}$ cutoff wavelength. The geostrophic velocity component perpendicular to the reference track is then derived using the thermal wind equation referenced to $500 \mathrm{~m}$ (see Carret et al., 2019 for further details).

\section{1.c) Satellite altimetry}

Jason 2 was launched in June 2008 and was in the same orbit up to October 2016. It is based on a conventional Low Resolution Mode (LRM) altimeter operating in the $\mathrm{Ku}$-band and has a

10-day repetition cycle. SARAL, launched in February 2013 moved to a drifting orbit in July 2016, providing a shorter data time series (3 years). It has a 35-day repeat observation cycle. However, with its LRM altimeter operating in the Ka-band (called AltiKa), it has a lower data noise and is expected to capture smaller spatial scales than Jason 2 (Verron et al., 2018). Sentinel-3 was launched in February 2016. With its SAR (Synthetic Aperture Radar) altimeter, its footprint is further reduced in the along-track direction, compared to SARAL. Sentinel-3 has a 27-day repeat observation cycle. Figures $2 b, c, d$ indicate the satellite tracks of each mission in the NWMed, defining the spatial coverage of the corresponding nadir altimetry observations. Note that the spatial resolution of nadir $1-\mathrm{Hz}$ altimetry data is in the range 5-8 km along the track (Table 1) but that the inter-track distance varies from $230 \mathrm{~km}$ for Jason 2 to $76 \mathrm{~km}$ for Sentinel-3 and $58 \mathrm{~km}$ for SARAL. For each mission, the tracks used in this study are indicated in bold in Fig. 2b,c,d. They correspond to the tracks closest to HF radars data (see below for explanation): the Sentinel-3 track 472 and the SARAL track 302 pass over the HF radars region with a different angle, whereas the Jason 2 track 222 is located a bit further to the east, at about $60 \mathrm{~km}$. Table 1 summarizes the characteristics of each 190 altimetry dataset. 
For all missions, we use the X-TRACK regional product processed with a coastal oriented strategy described in Birol et al. (2017) (DOI: 10.6096/CTOH_X-TRACK_2017_02) that provides $1-\mathrm{Hz}$ Sea Level Anomaly (SLA) time series homogeneously processed and regularly spaced (Table 1, along-track resolution) along the different satellite tracks. The processing is the same for all missions, except that the dual-frequency of Jason 2 and Sentinel-3 altimeters allows to compute the ionosphere correction whereas a model is required for SARAL. This correction being associated with long wavelengths, it should not impact the results obtained in this study.

From SLA data, the across-track geostrophic current $(u)$ can be inferred through the geostrophic equation (Eq. 1) after adding a regional Mean Dynamic Topography (MDT, Rio et al., 2014) .

$205 \mathrm{u}=\frac{-g}{f} \quad \frac{\Delta(S L A+M D T)}{\Delta x}$

where $g$ is the gravitational constant, $f$ the Coriolis parameter and $\Delta x$ the distance between the $1-\mathrm{Hz}$ altimetry points. Before computing current estimates, the SLA may be filtered in the along track direction in order to remove the remaining altimetry noise. In this study the filtering is applied in Section 4.2 but not in Section 4.1. When used, the filtering is done with a low-pass Loess filter using different cut-off wavelengths (see Section 4.2).

\subsection{Model}

We rely here on the SYMPHONIE primitive equation model which has been widely used in the study area at the nearshore (Michaud et al., 2012), coastal (Estournel et al., 2003; Mikolajczak et al., 2020; Petrenko et al., 2008) and regional (Estournel et al., 2016) scales.

SYMPHONIE is described in Marsaleix et al. (2008, 2006), Damien et al. (2017), with turbulence closure and convection parameterization detailed in Estournel et al. (2016). The configuration used in this study covers the whole Mediterranean basin, the Marmara Sea and extends westward up to $8^{\circ} \mathrm{W}$ in the Gulf of Cadiz; it is described in Estournel et al. (2021). The horizontal resolution is minimum $(2 \mathrm{~km})$ in the northwestern Mediterranean (except for a local narrowing at the Gibraltar strait). A VQS (vanishing quasi-sigma) vertical coordinate (Estournel et al., 2021) with 50 levels is used. The model is initialized and forced at its open boundaries with analysis produced by the operational oceanography center MERCATOR OCEAN International, (MOI, Lellouche et al., 2013). As stratification is crucial for mesoscale characteristics, it has been debiased from observations collected over the whole basin as in Estournel et al. (2016) while preserving the first hundred meters which benefits optimally from the data assimilation performed at MOI. At the air/sea interface the hourly forecasts of ECMWF at the horizontal resolution of $0.125^{\circ}$ are used to calculate heat and momentum fluxes through bulk formulae. 
The model simulation covers the period from 18 May 2011 to 31 March 2017 and provides 4day averaged fields. Daily outputs are also available during the period of HF radars availability and will be used in the validation exercise (section 2.3).

\subsection{Simulation validation}

235 The first step of this study is to validate the model simulation in terms of surface current which is here the variable of interest. The currents deduced from the gliders and HF radars are compared to their equivalent in the simulation: geostrophic ones for the glider, total currents for the radars. The representation of the NC is compared using statistics (timeaverage and standard deviation) and time-space diagrams (Hovmuller diagrams).

For the comparison with the HF radars, we consider the zonal current component from May 2012 to September 2014 along a section located at $6.14^{\circ} \mathrm{E}$, just south of Toulon (Fig. 2). Note that, due to the coast configuration in this area, the NC which follows the $1000-2000 \mathrm{~m}$ isobaths is mainly westward, i.e. with a dominant zonal component most of the time (with the exception of short living, 3-6 days, meanders or wind-induced instabilities). Figure 3a shows the time-average and standard deviation of the zonal velocity as a function of latitude along this section. At this longitude, the NC flows westward and corresponds then to the negative values observed north of $42.7^{\circ} \mathrm{N}$. In terms of statistics, there is an excellent agreement between the $\mathrm{HF}$ radars and the simulation. On average, the $\mathrm{NC}$ position and current amplitude are almost identical in both fields. The maximum NC amplitude (called Vmax hereinafter) is $-0.44 \pm 0.16 \mathrm{~m} \mathrm{~s}^{-1}$ for the simulation and $-0.43 \pm 0.19 \mathrm{~m} \mathrm{~s}^{-1}$ for the radars. This velocity value, identified as the $\mathrm{NC}$ core, is located at $42.85^{\circ} \mathrm{N}$ for both simulation and observations. We define the width of the $\mathrm{NC}$ as the length of the section around its core where the absolute velocity is larger than $|\mathrm{Vmax}| / 2$. On average, it is $18 \pm 5.9 \mathrm{~km}$ for the simulation and $18 \pm 6.1$

$255 \mathrm{~km}$ for the observations. The main difference along the section is that between the $\mathrm{NC}$ and the coast (to the north), where the velocity variability is slightly greater for the HF radars than for the simulation.

In order to investigate the representation of the $\mathrm{NC}$ variability in the simulation in more detail, Fig. $3 \mathrm{c}$ represents the time space diagrams of the zonal velocity along $6.14^{\circ} \mathrm{E}$ for both the HF radars and the simulation and the differences between both fields. We observe an overall good agreement between the observations and the simulation, both estimates showing the same seasonal variability, i.e. larger velocities in winter and spring and a summer slow down, and a similar high frequency variability that may instantiate the wind-induced (Ekman current) and mesoscale (meanders and eddies) variability of the circulation. The differences between the currents' estimates are generally low and higher values (order of a few tens of $\mathrm{cm} \mathrm{s}^{-1}$ ) can be largely explained given the fact that short-living structures may not strictly coincide in time and space in the model and observations. 
270 The same diagnostics have been computed for the simulation and the glider data along the Nice-Calvi section, located further east (Fig. 3b,d) but in this case with the geostrophic current component normal to the section. We also observe a good agreement between the simulation and the gliders but with more differences than what was obtained with the radars, especially in terms of current variability. We obtain Vmax values of $-0.23 \pm 0.12 \mathrm{~m} \mathrm{~s}^{-1}$ for the

275 model and $-0.25 \pm 0.13 \mathrm{~m} \mathrm{~s}^{-1}$ for the gliders. Near the coast the differences between the observed and simulated mean currents can reach $0.1 \mathrm{~m} \mathrm{~s}^{-1}$. The NC core is located at $43.51^{\circ} \mathrm{N}$ for the simulation and at $43.52^{\circ} \mathrm{N}$ for the observations. The $\mathrm{NC}$ is thus well located in the simulation, but narrower $(24 \pm 6.6 \mathrm{~km})$, compared to the observations $(30 \pm 9.6 \mathrm{~km})$. Concerning the time-space diagrams, the instantaneous differences in velocity between the observations and the simulation can reach $0.5 \mathrm{~m} \mathrm{~s}^{-1}$. They are associated with a misplaced current in the model rather than with incorrect current values. The irregular temporal sampling of the gliders also contributes to these larger model-data differences, compared to the HF radars results. Indeed, a deeper analysis shows that the same features may occur in the simulation and in the observations, but shifted by one or two days (not shown).

Finally, we have used all the observations available (glider, HF radars and altimetry) in order to have a general view of the model ability to represent the regional circulation in our study area (Fig. 4). For the sake of clarity, we chose to represent for SARAL only the tracks closest to in situ observations in order to not overload the figure. We compute the time-average and the standard deviation of surface current perpendicular to the tracks derived from all observations and from the simulation collocated in space and time with the observations (Fig. 4). These statistics are computed over the common period of data availability (if we consider only SARAL and Jason-2 in terms of altimetry missions): from March 2013 to October 2014. Both a regional view of the NW Mediterranean Sea and a zoomed-in view of the northern

295 Ligurian Sea are provided. Note that the observation component of these diagnostics (top panels) have already been shown in Carret et al. (2019) to analyze how the NC is captured by the different types of instruments while the focus here is on the simulation quality. In Fig. 4a and $\mathrm{c}$, the NC corresponds to the negative velocity values (westward flow) represented in blue along the French and northern Spanish continental slope. As already indicated in Carret 300 et al. (2019), the continuity of the circulation emerges when putting together the different instruments which show a very good consistency in terms of mean current. The model also shows this continuity with almost identical current values: around $-0.19 \mathrm{~m} \mathrm{~s}^{-1}$ south of Nice against $-0.24 \mathrm{~m} \mathrm{~s}^{-1}$ for the gliders and around $-0.42 \mathrm{~m} \mathrm{~s}^{-1}$ south of Toulon against $-0.41 \mathrm{~m} \mathrm{~s}^{-1}$ for the HF radars. The standard deviation of the current is larger along the NC. It is captured by all types of observations but with differences from one instrument to the other (see Carret et al., 2019 for analysis). These differences due to the sampling bias and the spatial variability are also observed in the simulated field, although the corresponding standard deviations are weaker. At the $\mathrm{HF}$ radars location, the $\mathrm{NC}$ variability results in standard deviation values of $0.24 \mathrm{~m} \mathrm{~s}^{-1}$ for the observations and $0.14 \mathrm{~m} \mathrm{~s}^{-1}$ for the simulation, which is coherent with what

310 is observed on Fig. 3. The variability is less important for altimetry data which don't get as close to the coast as in situ observations and measure a different geophysical content than the 
observations. Carret et al. (2019) showed that these differences mainly come from the temporal resolution and the number of data samples.

315 All these results show that the simulation has excellent skills in terms of circulation, as well at the regional scale all along the NC paths than at the local one in the vicinity of the HF radars and glider covered areas.

\section{Signature of the NC on sea level}

The good results obtained above in the Ligurian Sea in terms of model-data comparison allow us to use the simulation as a reference for altimetry data analysis. It is first used to quantify the NC sea level signature before analyzing how it is captured by altimetry data (section 4). We first describe how we quantify this signature over the area covered by the HF radars observations.

In the simulation, we first extracted the sea level profiles for each date along the section located at $6.14^{\circ} \mathrm{E}$ (see Fig. 2a). The corresponding cross-transect surface geostrophic current component is then calculated using Eq. 1, as for classical altimetry estimates.

For each SSH profile, we use three diagnostics to characterize the NC sea level signature.

330 First, the location of the NC core, corresponding to the maximum velocity in absolute value, is spotted on the cross-shore current profile (expressed as a distance to the coast). Then, the drop in SSH (called diff) is computed over the region delimited by velocity values higher than half of the NC core velocity (Eq. 2).

$$
\operatorname{diff}=\max \left(S S H_{|u| \geq \frac{|u| \max }{2}}\right)-\min \left(S S H_{|u| \geq \frac{|u| \max }{2}}\right)
$$

335 Finally the width $(d x)$ of this region, defining the $\mathrm{NC}$ width, is derived as the distance between the two half $\mathrm{NC}$ core velocities.

Figure 5 illustrates the methodology described above for the model SSH and corresponding zonal current profiles along the $6.14^{\circ} \mathrm{E}$ transect and averaged over the HF radars period. The profiles are represented as a function of the distance to the coast. On Fig. 5a, the dashed

340 vertical lines delimit the $\mathrm{NC}$ width. They are transposed on Fig. $5 \mathrm{~b}$ in order to derive the corresponding SSH drop (diff value).

We observe that, on average, the SSH decreases from $8 \mathrm{~km}$ to $28 \mathrm{~km}$ to the coast, i.e. the distance $d x$. This corresponds to the NC associated with negative zonal velocity values. Still on average, the $\mathrm{NC}$ core velocity is $-0.39 \mathrm{~m} \mathrm{~s}^{-1}$ and is at about $18 \mathrm{~km}$ from the coast. It

345 corresponds to a drop in sea level of $6.9 \mathrm{~cm}$ over $20 \mathrm{~km}$. These values are considered as the mean sea level signature of the $\mathrm{NC}$ in the area considered. 
The time series of the three diagnostics defined above along the $6.14^{\circ} \mathrm{E}$ transect are represented in Fig. 5c. The SSH drop associated with the $\mathrm{NC}$ varies between $2 \mathrm{~cm}$ and $15 \mathrm{~cm}$, with a clear seasonal tendency. Greater values are generally observed in winter and smaller values in summer. The $\mathrm{NC}$ core position varies between 10 and $30 \mathrm{~km}$ from the coast $(30 \mathrm{~km}$ in Alberola et al., 1995) with a slight seasonal variation. It is a little closer to the coast in autumn than in winter, in agreement with Niewiadomska et al. (2008) and Sammari et al. (1995), even if these previous studies were not in the Toulon area. The NC width spreads over 10 to $25 \mathrm{~km}$, depending on the season (it is the widest in January and July and the narrowest in March and April). Previous studies show a NC narrower and faster in winter, it may depend on the $\mathrm{NC}$ orientation in relation to the section: a NC not purely perpendicular may artificially increase the current width. In the different diagnostics, the high frequency variability is also important, with some strong peaks. This may be due to intense wind events which induce meanders or eddies in the HF radars area (Guihou et al., 2013). Note that in August 2013, the NC core shifted until $50 \mathrm{~km}$ from the coast, associated with a large width and strong SSH drops (Fig. 5c). It is also visible on Fig. 3 for both the simulation and the radars. We investigated what happened for the corresponding dates, from 25 to 28 August 2013, in both simulated and observed surface currents (not shown). We observed that the NC is then totally deviated to the south and is cut in two parts, with a recirculation loop that comes from the south-west and blocks the NC flow.

In terms of SSH drop, the NC signature is then generally above the global rms mean error level for the altimetry missions considered here (from Vergara et al., 2019: 2.23/1.66/1.12 cm for Jason-2/SARAL/S3A, respectively). But its width is generally below the scales resolved (from Raynal et al. (2017), Jason satellites can capture offshore dynamical signals down to $\sim 70$ $\mathrm{km}$ wavelength, SARAL/AltiKa and Sentinel-3 down to 35-50 km). We also know that the observation of near-shore SSH estimates is a technical challenge for altimetry (Vignudelli et al., 2011). In the next section, using the model as the reference, we analyze which part of the $\mathrm{NC} \mathrm{SSH}$ and current signals are really sampled by altimetry data.

\section{Observability of the NC in altimetry data: from Jason-2 to Sentinel-3}

In this section, we first analyze the general characteristics of the SSH and surface (crosssection) velocity profiles observed along the selected tracks (see section 2.1 and Fig. 2) for both altimetry data and the model reference (section 4.1). The altimetry data noise issue is then investigated in section 4.2.

\subsection{SSH and current statistics}

We compute the temporal mean and standard deviation of the individual SSH and 
corresponding cross-track velocity profiles (using the geostrophic equation) observed along

Jason 2 track 222, SARAL track 302 and Sentinel-3 track 472 (Fig. 6). The corresponding model estimates at the dates closest to altimetry are also calculated and shown in the same figures. The model fields are interpolated at the $1-\mathrm{Hz}$ altimetry points along each track (i.e. every 6-7 $\mathrm{km}$ depending on the altimetry mission). Note that here, no spatial filtering is applied on altimetry data, neither on the SSH nor before computing the geostrophic velocities, because we want to analyze the resolution capability of raw sea level data. For Jason-2 and SARAL, the time periods considered are the common periods between observations and the model simulation: 27/05/2011-01/10/2016 for Jason-2 and 24/03/2013 to $13 / 03 / 2016$ for SARAL. For Sentinel-3, the common period of model and data availability is very short (18/06/2016 to $15 / 03 / 2017)$. We then chose to use the total period of Sentinel-3 data availability (18/06/2016 to 14/03/2019) and the period 21/06/2014 to $15 / 03 / 2017$ for the model (same length but different years). To estimate the impact of this choice on the results, we performed a sensitivity analysis by computing the mean current and the mean SSH of the model (same diagnostics than those on Fig. 6) over different 3-year time periods: over 10/06/2011 - 31/03/2014, 22/06/2012 - 17/03/2015, 08/06/2013 - 29/03/2016. The results are

405 very similar (not shown), which indicates that in this area the interannual variability does not have a strong imprint on our results.

The three diagnostics defined in section 3 are considered for each mission - the SSH drop associated with the $\mathrm{NC}$, the $\mathrm{NC}$ width and the distance to the coast of the $\mathrm{NC}$ core - and extended up to $120 \mathrm{~km}$ of the coast. The statistics are computed with 195, 32, 36 samples for Jason-2, SARAL and Sentinel-3, respectively.

We first focus on Jason-2 results. In Fig. 6a, we observe that on average, the raw altimetry SSH profile agrees fairly well with the model above $20 \mathrm{~km}$ from the coast; below this distance, the two curves diverge with a steeper slope for Jason 2. In this area, the SSH increase corresponding to the external edge of the $\mathrm{NC}$ starts at $60 \mathrm{~km}$ to the coast, i.e. further from the coast than for the $6.14^{\circ} \mathrm{E}$ transect (located to the west). The $1-\mathrm{Hz}$ altimetry SSH data stops at $8 \mathrm{~km}$ from the coast. SSH standard deviations from altimetry are slightly greater (between 0.8 and $1.6 \mathrm{~cm}$ ) than from the model, except at the nearest point to the coast where the difference reaches $2.2 \mathrm{~cm}$. Figure $6 \mathrm{~b}$ shows the corresponding mean cross-track velocity profiles. Jason-2 solution is noisier than the model one. Here again, above $20 \mathrm{~km}$ from the coast the two mean curves agree well but when approaching the coast, the steeper slope observed in Jason-2 SSH results in too high near-coastal velocity values and then a larger $\mathrm{NC}$, in comparison to the model. The standard deviation of Jason 2 velocities is about three times higher than for the model $\left(0.34 \mathrm{~m} \mathrm{~s}^{-1}\right.$ against $\left.0.092 \mathrm{~m} \mathrm{~s}^{-1}\right)$.We also observe that the current variability tends to decrease near the coast in the model, whereas it increases in the observations, likely due to nearshore increased altimetry noise.

Figure 6c,d shows the same analysis for SARAL. It should be kept in mind that the 35-day cycle of SARAL and its shorter lifetime lead to a significantly smaller number of samples to compute the statistics compared to Jason-2. Figure 6c shows the SSH profiles. Here, 1-Hz 
altimetry data stops at $16 \mathrm{~km}$ from the coast. The SARAL and model curves have more or less similar slopes but SARAL SSH begins to increase much further from the coast than the simulated SSH (70 km vs $50 \mathrm{~km}$ ). On the contrary to Jason 2, the SARAL SSH variability is quite similar (std difference of $0.5 \mathrm{~cm}$ ) to the simulated one near the coast. The corresponding mean velocity profiles have similar shapes, but slightly more spreaded offshore for altimetry (Fig. 6d). The SARAL-derived currents are less noisy than Jason 2 ones but with still greater variability than the model reference (std of $0.16 \mathrm{~m} \mathrm{~s}^{-1}$ for SARAL raw data, and $0.068 \mathrm{~m} \mathrm{~s}^{-1}$ for the model).

440 Finally, we repeated the process for Sentinel-3 (Fig. 6e,f). As explained before, the model is shifted in time in order to have enough data to compute statistics. In terms of SSH profile (Fig. 6e), Sentinel-3 appears very similar to SARAL (Fig. 6c). SSH increases further south for the observations than for the model, leading to a slightly more offshore extended current. Compared to Jason 2 and SARAL, Sentinel-3 1-Hz data get much closer to the coast (around

$4451 \mathrm{~km}$ ), and are also less noisy with SSH standard deviation quite identical to the model near the coast and slightly higher far from the coast. Figure $6 \mathrm{f}$ shows that, thanks to its better coastal data coverage, Sentinel-3 captures the NC almost entirely. The current variability remains quite important along the track compared to the model $\left(0.19 \mathrm{~m} \mathrm{~s}^{-1}\right.$ for altimetry against $0.065 \mathrm{~m} \mathrm{~s}^{-1}$ for the model in average) and a huge standard deviation value characterizes the first point near the coast.

From the results of Fig. 6, we computed the time-averaged NC characteristics (SSH drop, NC width and distance to the coast of the $\mathrm{NC}$ core). The results are summarized in Table 2. For Jason 2, the NC signature in SSH is significantly stronger than that seen by the model sampled as altimetry: $10.2 \mathrm{~cm}$ and $7.2 \mathrm{~cm}$ respectively. This is mainly due to the divergence between the model and altimetry SSH near the coast. SARAL is very close to the model: 7.1 $\mathrm{cm}$ against $6.8 \mathrm{~cm}$. Sentinel-3 is in between, with a drop of $8.2 \mathrm{~cm}$ vs $6.8 \mathrm{~cm}$ for the model. The NC width is slightly larger in altimetry than in the model $(+6 /+5 /+1 \mathrm{~km}$ for Jason2/SARAL/Sentinel-3, respectively). In Jason-2 and Sentinel-3, the NC core is located at the 460 same distance to the coast as in the model, but it is located $8 \mathrm{~km}$ further from the coast in SARAL. Note also that the NC is better (almost entirely) resolved in Sentinel-3, compared to Jason-2 and SARAL.

\subsection{The altimetry data filtering issue}

In practice, users systematically apply a spatial filter to altimetry SSH data before geostrophic current derivation, an operation that strongly amplifies the measurement noise, as observed in section 4.1. The SSH filtering step is then a key element of altimetry current computation and it is even more true in coastal areas. Consequently, the capability of altimetry to capture mesoscale currents depends on the choice of the filter.

Figure 7 illustrates this noise issue by presenting the time space diagram of SSH derived from 
the model and from 1-Hz altimetry raw data along the Jason 2 track 222 in the $120 \mathrm{~km}$ close to the coast. Note that with Jason-2, for the reason explained before, near-shore data are often missing. If the evolution of both SSH fields is globally similar, we clearly observe noise in altimetry data as well as larger differences near the coast (i.e. in the first $30 \mathrm{~km}$ ).

To estimate the best SSH filtering for the derivation of current estimates, we compute the distribution of the resulting geostrophic velocity values, using raw and low-pass filtered SSH altimetry data in the $60 \mathrm{~km}$ close to the coast. We compare the results to the distribution of the corresponding model velocities, used here again as a reference. To obtain the filtered $\mathrm{SSH}$, we tested different cutoff frequencies, ranging from $30 \mathrm{~km}$ to $50 \mathrm{~km}$ for SARAL and Sentinel-3 and extending to $70 \mathrm{~km}$ for Jason 2. Indeed, Morrow et al. (2017) and Raynal et al. (2017) showed a greater noise level in Jason 2 which required larger cutoff frequency values. The histograms of current values are represented in Fig. 8 for Jason 2 track 222, in Fig. 9 for SARAL track 302 and in Fig. 10 for Sentinel-3 track 472 (altimetry in blue superposed on the model in pink). Note that for each mission, the model current values are sampled at altimetry temporal resolution (10, 35 and 27 days for Jason 2, SARAL and Sentinel-3 respectively) and at the model resolution to investigate the impact of undersampling data (bottom figures). Table 3 summarizes the statistics derived from the histograms: the median, 490 the standard deviation, as well as the number of points outside typical current values in this area and considered as outliers (greater than $0.25 \mathrm{~m} \mathrm{~s}^{-1}$ and smaller than $-0.6 \mathrm{~m} \mathrm{~s}^{-1}$. These values are considered the typical $\mathrm{NC}$ velocities).

We first focus on Jason 2. The model reference shows a distribution which tends to be 495 gaussian. It is centered around $-0.15 \mathrm{~m} \mathrm{~s}^{-1}$, with a majority of negative values and is slightly asymmetric. Jason-2 raw velocity values are almost randomly distributed. When Jason-2 SSH data are filtered, and as the cutoff wavelength increases, the histogram's distributions change and get closer to the model ones. Regarding the statistics (Table 3), the too high standard deviation and too negative median values in the raw Jason-2 data get closer to the reference with the increase in cutoff wavelength. With a $60 \mathrm{~km}$ - filtering, we have the same standard deviation values in both Jason-2 and model velocities but the median value remains always significantly lower in Jason-2. The number of outliers is also too large in raw Jason-2 data, but decreases rapidly with the filtering; it is the closest to the model reference for a $60 \mathrm{~km}$ filtering. From these results we conclude that Jason 2 currents tend to best converge towards

505 the model reference with a filtering at $60 \mathrm{~km}$. Beyond this cutoff wavelength, the smoothing erases the left and right-hand sides of the distribution (Fig. 8) and reduces the variability.

We repeat the same analysis with SARAL (Fig. 9 and Table 3). Note that there are fewer satellite cycles for SARAL than for Jason 2, so less current data are available to compute statistics. As a result, the distributions obtained are more complex than for Jason-2. It is

510 clearly observed when comparing Fig. 9e and $\mathrm{f}$ (distributions computed at the model resolution and at a 35-day resolution). The model histogram is initially centered on $-0.07 \mathrm{~m} \mathrm{~s}^{-}$ ${ }^{1}$ with an asymmetric shape and a slight secondary peak around $-0.25 \mathrm{~m} \mathrm{~s}^{-1}$. When using the SARAL temporal resolution, the distribution is more random with a peak around $-0.07 \mathrm{~m} \mathrm{~s}^{-1}$. 
The raw altimetry solution is less randomly distributed than for Jason 2, also confirmed by a standard deviation value 2 times smaller than for Jason-2, $0.18 \mathrm{~m} \mathrm{~s}^{-1} \mathrm{vs} 0.36 \mathrm{~m} \mathrm{~s}^{-1}$ and already relatively close to the $0.15 \mathrm{~m} \mathrm{~s}^{-1}$ model reference. SARAL tends to converge towards the model with a filtering of $30 \mathrm{~km}$.

For Sentinel-3, the distribution of the raw altimetry solution has a bimodal shape (Fig. 10a) as in the model. Its standard deviation is also largely closer to the model reference, compared to Jason-2 (but slightly less than SARAL, Table 3). The statistics of the altimetry velocities tend to converge towards the model reference with a $40-50-\mathrm{km}$ cutoff wavelength. One of the reasons for the slightly bimodal distribution in SARAL and Sentinel-3 may be the track orientation, quite different from the Jason 2 track which is perpendicular to the NC (Fig. 2e). Testing different track angles reveals indeed a small second peak (not shown).

\section{Summary and conclusion}

530 In this study, we have presented a novel method to quantify the SSH signature of a narrow slope current, the Northern Current in the North Western Mediterranean Sea, and to define its observability in altimetry data. It is based on a high resolution numerical model, intensively validated against in situ and HF radars data, and then considered as a reference for satellite altimetry data analysis. We consider the SSH and related surface geostrophic currents in

535 parallel, using three nadir-looking radar altimeters that employ different technologies: Jason2, SARAL and Sentinel-3. We investigate how the advances in performance of these altimeters (Vergara et al., 2019) improve the observation of the NC.

We show that in the HF radars covered region the $\mathrm{NC}$ has a clear signature in $\mathrm{SSH}$, characterized by a sea level drop from offshore to the coast, generally centered at $\sim 15-20 \mathrm{~km}$

540 to the coast with a mean value at $6.14^{\circ} \mathrm{E}$ of $6.9 \pm 2.2 \mathrm{~cm}$ and spreading over $18 \pm 4 \mathrm{~km}$. In winter, the SSH drops are generally stronger than in summer and then theoretically easier to detect for altimeters but in parallel, the NC width also tends to diminish, inducing opposite effects in terms of observability capability. Sammari et al. (1995) have noticed a variability of the alongslope component of the NC between 10 and 20 days that altimetry does not allow to

545 resolve. These results confirm that as a narrow, variable and close to the coast current, the NC monitoring is an issue for satellite altimetry and that the larger the temporal resolution of the mission, the greater the difficulty. This is particularly true for SARAL and Sentinel-3, regardless of the instrument performance.

We then analyze the NC signature in altimetry data in comparison to the model reference. Jason 2 and SARAL 1-Hz data stop at more than $10 \mathrm{~km}$ to the coast, sometimes preventing observation of the whole NC. Probably thanks to the SAR mode, it is resolved in Sentinel-3, with data at $1 \mathrm{~km}$ to the coast. In average, the $\mathrm{SSH}$ drops associated with the $\mathrm{NC}$ are always 
too high in altimetry, with mean values of $3.6 \mathrm{~cm}, 0.3$ and $1.4 \mathrm{~cm}$ larger for Jason 2, SARAL and Sentinel-3, respectively. The mean NC core location is correctly located in Jason 2 and Sentinel-3 but it is slightly shifted in SARAL (an $8 \mathrm{~km}$ difference between the model and observations). In terms of current variability, Sentinel-3 and SARAL have much lower values than Jason-2 (which remain 3.7 times larger than the model reference). These too high values are of course largely explained by the measurement noise, significantly decreasing in the most recent altimetry missions. In section 4.1 , we observe how this noise reduction has a strong impact on the quality of velocity derived from SSH, with the best performance obtained with SARAL data. However, the signal-over-noise ratio remains too large and all satellite SSH data must clearly be filtered before computing currents. By comparing the distributions of altimetry velocity fields derived with different filtering strategies with the model reference, we find that the optimal cutoff wavelength is $60 \mathrm{~km}, 30 \mathrm{~km}$ and $40-50 \mathrm{~km}$ for Jason-2, SARAL and Sentinel-3 SSH data, respectively. Note that these values are slightly lower than the numbers given in Raynal et al. (2017): $\sim 70 \mathrm{~km}$ for Jason-2 and 35-50 km for SARAL/AltiKa and Sentinel-3, even if these studies focused on open ocean data. Morrow et al. (2017) also found values similar to Raynal et al. (2017) for Jason 2 and SARAL missions through spectral analysis.

570 In summary, in terms of coastal circulation studies, the main advantages of Jason missions are the long time series ( $\sim 30$ years if we combine T/P and Jason-1,2,3 data) and its 10-day temporal resolution whereas its measurement noise, its large intertrack distance and its loss of coastal data are an issue. SARAL enables to strongly reduce the data noise and to have a much better spatial coverage but its temporal resolution and its loss of coastal data are negative points. Finally

575 Sentinel-3 performs the best when approaching the coast and its SAR technique also allows to reduce the noise. However, it has a too low temporal resolution. To ideally address the coastal observability question, future altimetry missions should combine instrumental improvements (Ka band and SAR altimetry as in SARAL and Sentinel-3) and the temporal resolution of Jason or better. But a single altimeter mission can clearly not observe the complex range of 580 coastal ocean variability and we should certainly define an approach optimized for the coastal ocean in order to mix data from the 9 missions flying simultaneously in 2021.

The method presented here can be easily transposed to other altimetry missions and other dynamical processes than the NC. As an example, we could also focus on eddy observability, studying the size, amplitude and spatial configuration of their signature in $\mathrm{SSH}$, in comparison to the model reference. More generally, this study illustrates the benefits of using a carefully calibrated high-resolution model as a reference for coastal altimetry studies. It allows overcoming the sparsity of independent observations needed to validate near-shore altimetry observational data. Models can be used as a reference to compare the performance of different altimetry missions, but also to compare or calibrate coastal data processing strategies. And finally, they provide 3D information on the whole range of ocean parameters that can be related to the sea level variations captured by altimetry. 


\section{Acknowledgements}

595 This study was done with the financial support of the Region Occitanie and the CNES through their $\mathrm{PhD}$ funding programs. Altimetry data used in this study were developed, validated and distributed by the CTOH/LEGOS, France. Glider data were collected and made freely available by the Coriolis project (http://www.coriolis.eu.org) and programs that contribute. Support was provided by the French Chantier Méditerranée MISTRALS program

600 (HyMeX and MERMeX components) and by the EU projects FP7 GROOM (grant agreement 284321), FP7 PERSEUS (grant agreement 287600), FP7 JERICO (grant agreement 262584) and the COST Action ES0904 EGO (Everyone's Gliding Observatories). The long-term monitoring of the Northern Current is part of the Mediterranean Ocean Observation Service for the Environment (MOOSE) with HF radars activities also supported by the EU H2020 infrastructure project JERICO-NEXT (2015-2019) and actually by EU Interreg Marittimo program SICOMAR- PLUS. We thank the Parc National de Port-Cros (PNPC), "Association Syndicale des Propriétaires du Cap Bénat" (ASPCB) and the Group Military Conservation and the Marine Nationale for hosting our radar installations. The simulation was performed using the HPC CALMIP platform under grant_P09115 and GENCI and CINES (Grand

610 Equipement National de Calcul Intensif, project A0040110088). The SYMPHONIE model is distributed by the SIROCCO group (https://sirocco.obs-mip.fr).

\section{Bibliographie}

Alberola, C., Millot, C., and Font, J.: On the seasonal and mesoscale variabilities of the 615 Northern Current during the PRIMO-0 experiment in the western Mediterranean-sea, 18, 163-192, 1995.

Birol, F. and Delebecque, C.: Using high sampling rate $(10 / 20 \mathrm{~Hz})$ altimeter data for the observation of coastal surface currents: A case study over the northwestern Mediterranean Sea, Journal of Marine Systems, 129, 318-333, 620 https://doi.org/10.1016/j.jmarsys.2013.07.009, 2014.

Birol, F., Cancet, M., and Estournel, C.: Aspects of the seasonal variability of the Northern Current (NW Mediterranean Sea) observed by altimetry, Journal of Marine Systems, 81, 297311, https://doi.org/10.1016/j.jmarsys.2010.01.005, 2010.

Birol, F., Fuller, N., Lyard, F., Cancet, M., Niño, F., Delebecque, C., Fleury, S., Toublanc, F.,

625 Melet, A., Saraceno, M., and Léger, F.: Coastal applications from nadir altimetry: Example of the X-TRACK regional products, Advances in Space Research, 59, 936-953, https://doi.org/10.1016/j.asr.2016.11.005, 2017.

Birol, F., Léger, F., Passaro, M., Cazenave, A., Niño, F., Calafat, F. M., Shaw, A., Legeais, J.F., Gouzenes, Y., Schwatke, C., and Benveniste, J.: The X-TRACK/ALES multi-mission 
630 processing system: New advances in altimetry towards the coast, Advances in Space Research, 67, 2398-2415, https://doi.org/10.1016/j.asr.2021.01.049, 2021.

Borrione, I., Oddo, P., Russo, A., and Coelho, E.: Understanding altimetry signals in the Northeastern Ligurian sea using a multi-platform approach, Deep Sea Research Part I: Oceanographic Research Papers, 145, 83-96, https://doi.org/10.1016/j.dsr.2019.02.003, 2019.

635 Bouffard, J., Vignudelli, S., Herrmann, M., Lyard, F., Marsaleix, P., Ménard, Y., and Cipollini, P.: Comparison of Ocean Dynamics with a Regional Circulation Model and Improved Altimetry in the North-Western Mediterranean, Terr. Atmos. Ocean. Sci., 19, 117, https://doi.org/10.3319/TAO.2008.19.1-2.117(SA), 2008.

Carret, A., Birol, F., Estournel, C., Zakardjian, B., and Testor, P.: Synergy between in situ and 640 altimetry data to observe and study Northern Current variations (NW Mediterranean Sea), 15, 269-290, https://doi.org/10.5194/os-15-269-2019, 2019.

Casella, E., Molcard, A., and Provenzale, A.: Mesoscale vortices in the Ligurian Sea and their effect on coastal upwelling processes, Journal of Marine Systems, 88, 12-19, https://doi.org/10.1016/j.jmarsys.2011.02.019, 2011.

645 Damien, P., Bosse, A., Testor, P., Marsaleix, P., and Estournel, C.: Modeling Postconvective Submesoscale Coherent Vortices in the Northwestern Mediterranean Sea, 122, 9937-9961, https://doi.org/10.1002/2016JC012114, 2017.

Dufau, C., Orsztynowicz, M., Dibarboure, G., Morrow, R., and Traon, P.-Y. L.: Mesoscale resolution capability of altimetry: Present and future, 121, 4910-4927, 650 https://doi.org/10.1002/2015JC010904, 2016.

Estournel, C., Madron, X. D. de, Marsaleix, P., Auclair, F., Julliand, C., and Vehil, R.: Observation and modeling of the winter coastal oceanic circulation in the Gulf of Lion under wind conditions influenced by the continental orography (FETCH experiment), 108, https://doi.org/10.1029/2001JC000825, 2003.

655 Estournel, C., Testor, P., Damien, P., D’Ortenzio, F., Marsaleix, P., Conan, P., Kessouri, F., Madron, X. D. de, Coppola, L., Lellouche, J.-M., Belamari, S., Mortier, L., Ulses, C., Bouin, M.-N., and Prieur, L.: High resolution modeling of dense water formation in the northwestern Mediterranean during winter 2012-2013: Processes and budget, 121, 5367-5392, https://doi.org/10.1002/2016JC011935, 2016.

660 Estournel, C., Marsaleix, P., and Ulses, C.: A new assessment of the circulation of Atlantic and Intermediate Waters in the Eastern Mediterranean, 198, 102673, https://doi.org/10.1016/j.pocean.2021.102673, 2021.

Fu, L. L. and Le Traon, P.-Y.: Satellite altimetry and ocean dynamics, Comptes Rendus Geoscience, 338, 1063-1076, https://doi.org/10.1016/j.crte.2006.05.015, 2006.

665 Gourdeau, L., Verron, J., Chaigneau, A., Cravatte, S., and Kessler, W.: Complementary Use of Glider Data, Altimetry, and Model for Exploring Mesoscale Eddies in the Tropical Pacific Solomon Sea: MESOSCALE EDDIES IN THE SOLOMON SEA, J. Geophys. Res. Oceans, 122, 9209-9229, https://doi.org/10.1002/2017JC013116, 2017. 
Grilli, F. and Pinardi N.: The computation of Rossby radii of deformation for the

Guihou, K., Marmain, J., Ourmières, Y., Molcard, A., Zakardjian, B., and Forget, P.: A case study of the mesoscale dynamics in the North-Western Mediterranean Sea: a combined datamodel approach, Ocean Dynamics, 63, 793-808, https://doi.org/10.1007/s10236-013-0619-z, 2013.

675 Herrmann, M., Somot, S., Sevault, F., Estournel, C., and Déqué, M.: Modeling the deep convection in the northwestern Mediterranean Sea using an eddy-permitting and an eddyresolving model: Case study of winter 1986-1987, 113, https://doi.org/10.1029/2006JC003991, 2008.

Hu, Z. Y., Petrenko, A. A., Doglioli, A. M., and Dekeyser, I.: Study of a mesoscale anticyclonic eddy in the western part of the Gulf of Lion, Journal of Marine Systems, 88, 3 11, https://doi.org/10.1016/j.jmarsys.2011.02.008, 2011.

Jebri, F., Birol, F., Zakardjian, B., Bouffard, J., and Sammari, C.: Exploiting coastal altimetry to improve the surface circulation scheme over the central Mediterranean Sea, 121, 48884909, https://doi.org/10.1002/2016JC011961, 2016.

685 Juza, M., Renault, L., Ruiz, S., and Tintoré, J.: Origin and pathways of Winter Intermediate Water in the Northwestern Mediterranean Sea using observations and numerical simulation, 118, 6621-6633, https://doi.org/10.1002/2013JC009231, 2013.

Lellouche, J.-M., Le Galloudec, O., Drévillon, M., Régnier, C., Greiner, E., Garric, G., Ferry, N., Desportes, C., Testut, C.-E., Bricaud, C., Bourdallé-Badie, R., Tranchant, B., Benkiran,

690 M., Drillet, Y., Daudin, A., and De Nicola, C.: Evaluation of global monitoring and forecasting systems at Mercator Océan, 9, 57-81, https://doi.org/10.5194/os-9-57-2013, 2013.

Liu, J., Dai, J., Xu, D., Wang, J., and Yuan, Y.: Seasonal and Interannual Variability in Coastal Circulations in the Northern South China Sea, 10, 520, https://doi.org/10.3390/w10040520,

6952018

Marsaleix P., Auclair F., Estournel C.: Considerations on Open Boundary Conditions for Regional and Coastal Ocean Models. Journal of Atmospheric and Oceanic Technology, 23,1604-1613, http://dx.doi.org/10.1175/JTECH1930.1, 2006

Marsaleix, P., Auclair, F., Floor, J. W., Herrmann, M. J., Estournel, C., Pairaud, I., and Ulses,

700 C.: Energy conservation issues in sigma-coordinate free-surface ocean models, Ocean Modelling, 20, 61-89, https://doi.org/10.1016/j.ocemod.2007.07.005, 2008.

Michaud, H., Marsaleix, P., Leredde, Y., Estournel, C., Bourrin, F., Lyard, F., Mayet, C., and Ardhuin, F.: Three-dimensional modelling of wave-induced current from the surf zone to the inner shelf, 8, 657-681, https://doi.org/10.5194/os-8-657-2012, 2012.

705 Mikolajczak, G., Estournel, C., Ulses, C., Marsaleix, P., Bourrin, F., Martín, J., Pairaud, I., Puig, P., Leredde, Y., Many, G., Seyfried, L., and Durrieu de Madron, X.: Impact of storms on residence times and export of coastal waters during a mild autumn/winter period in the Gulf 
of Lion, Continental Shelf Research, 207, 104192, https://doi.org/10.1016/j.csr.2020.104192, 2020.

710 Millot, C.: Circulation in the Western Mediterranean Sea, Oceanologica Acta, 10, 143-148, 1987.

Morrow, R., Carret, A., Birol, F., Nino, F., Valladeau, G., Boy, F., Bachelier, C., and Zakardjian, B.: Observability of fine-scale ocean dynamics in the northwestern Mediterranean Sea, 13, 13-29, https://doi.org/10.5194/os-13-13-2017, 2017.

715 Niewiadomska, K., Claustre, H., Prieur, L., and d'Ortenzio, F.: Submesoscale physicalbiogeochemical coupling across the Ligurian current (northwestern Mediterranean) using a bio-optical glider, 53, 2210, 2008.

Pascual, A., Lana, A., Troupin, C., Ruiz, S., Faugère, Y., Escudier, R., and Tintoré, J.: Assessing SARAL/AltiKa Data in the Coastal Zone: Comparisons with HF Radar Observations, 38, 260-276, https://doi.org/10.1080/01490419.2015.1019656, 2015.

Petrenko, A., Dufau, C., and Estournel, C.: Barotropic eastward currents in the western Gulf of Lion, north-western Mediterranean Sea, during stratified conditions, Journal of Marine Systems, 74, 406-428, https://doi.org/10.1016/j.jmarsys.2008.03.004, 2008.

Raynal, M., Labroue, S., Urien, S., Amarouche, L., Moreau, T., Boy, F., Féménias, P., and Bouffard, J.: Performances and assessment of Cryosat-2 and Sentinel-3A SARM over ocean inferred from existing ground processing chains. Paper presented at Ocean Surface Topography Science Team Meeting (OSTST) 2017, Miami FL, United States of America.

Rio, M.-H., Pascual, A., Poulain, P.-M., Menna, M., Barceló, B., and Tintoré, J.: Computation of a new mean dynamic topography for the Mediterranean Sea from model outputs, altimeter measurements and oceanographic in situ data, 10, 731-744, https://doi.org/10.5194/os-10731-2014, 2014.

Sammari, C., Millot, C., and Prieur, L.: Aspects of the seasonal and mesoscale variabilities of the Northern Current in the western Mediterranean Sea inferred from the PROLIG-2 and PROS-6 experiments, Deep Sea Research Part I: Oceanographic Research Papers, 42, 893917, https://doi.org/10.1016/0967-0637(95)00031-Z, 1995.

Schaeffer, A., Molcard, A., Forget, P., Fraunié, P., and Garreau, P.: Generation mechanisms for mesoscale eddies in the Gulf of Lions: radar observation and modeling, Ocean Dynamics, 61, 1587-1609, https://doi.org/10.1007/s10236-011-0482-8, 2011.

Schroeder, K., Haza, A. C., Griffa, A., Özgökmen, T. M., Poulain, P. M., Gerin, R., Peggion, G., and Rixen, M.: Relative dispersion in the Liguro-Provençal basin: From sub-mesoscale to mesoscale, Deep Sea Research Part I: Oceanographic Research Papers, 58, 209-228, https://doi.org/10.1016/j.dsr.2010.11.004, 2011.

Troupin, C., Pascual, A., Valladeau, G., Pujol, I., Lana, A., Heslop, E., Ruiz, S., Torner, M., Picot, N., and Tintoré, J.: Illustration of the emerging capabilities of SARAL/AltiKa in the

745 coastal zone using a multi-platform approach, Advances in Space Research, 55, 51-59, https://doi.org/10.1016/j.asr.2014.09.011, 2015. 
Vergara, O., Morrow, R., Pujol, I., Dibarboure, G., and Ubelmann, C.: Revised Global Wave Number Spectra From Recent Altimeter Observations, 124, 3523-3537, https://doi.org/10.1029/2018JC014844, 2019.

750 Verron, J., Bonnefond, P., Aouf, L., Birol, F., Bhowmick, S. A., Calmant, S., Conchy, T., Crétaux, J.-F., Dibarboure, G., Dubey, A. K., Faugère, Y., Guerreiro, K., Gupta, P. K., Hamon, M., Jebri, F., Kumar, R., Morrow, R., Pascual, A., Pujol, M.-I., Rémy, E., Rémy, F., Smith, W. H. F., Tournadre, J., and Vergara, O.: The Benefits of the Ka-Band as Evidenced from the SARAL/AltiKa Altimetric Mission: Scientific Applications, 10, 163,

755 https://doi.org/10.3390/rs10020163, 2018.

Vignudelli, S., Cipollini, P., Astraldi, M., Gasparini, G. P., and Manzella, G.: Integrated use of altimeter and in situ data for understanding the water exchanges between the Tyrrhenian and Ligurian Seas, 105, 19649-19663, https://doi.org/10.1029/2000JC900083, 2000.

Vignudelli, S., Kostianoy, A.G., Cipollini, P., Benveniste, J.: Coastal Altimetry, Springer, 760 Berlin Heidelberg, 578 pp, doi:10.1007/978-3-642-12796-0. 2011

Zakardjian, B. and Quentin, C.: MOOSE HF radar daily averaged surface currents from MEDTLN site (Toulon NW Med), SEA-NOE, https://doi.org/10.17882/56500, 2018. 
https://doi.org/10.5194/os-2022-8

Preprint. Discussion started: 21 February 2022

(c) Author(s) 2022. CC BY 4.0 License.

Table 1: Characteristics of the altimetry datasets used in this study as a function of the satellite mission.

\begin{tabular}{|l|l|l|l|}
\hline & \multicolumn{3}{|c|}{ Altimetry mission } \\
\hline & Jason 2 & SARAL & Sentinel-3 \\
\hline Track used & 222 & 302 & 472 \\
\hline Data period & $\begin{array}{l}\text { June } 2008 \text { - October } \\
2016\end{array}$ & April 2013 - May 2016 & June 2016 - May 2019 \\
\hline $\begin{array}{l}\text { Intertrack distance } \\
\text { in the NW MedSea }\end{array}$ & $230 \mathrm{~km}$ & $58 \mathrm{~km}$ & $78 \mathrm{~km}$ \\
\hline Temporal resolution & 10 days & 35 days & 27 days \\
\hline Radar technology & $\begin{array}{l}\text { Conventional LRM } \\
\text { altimetry - Ku band }\end{array}$ & $\begin{array}{l}\text { Conventional LRM } \\
\text { altimetry - Ka band }\end{array}$ & $\begin{array}{l}\text { SAR altimetry - Ku } \\
\text { band }\end{array}$ \\
\hline $\begin{array}{l}\text { Along-track } \\
\text { resolution at 1-Hz }\end{array}$ & $5.8 \mathrm{~km}$ & $7.5 \mathrm{~km}$ & $6.7 \mathrm{~km}$ \\
\hline
\end{tabular}


https://doi.org/10.5194/os-2022-8

Preprint. Discussion started: 21 February 2022

(c) Author(s) 2022. CC BY 4.0 License.

Table 2: SSH drop, NC width and distance to the coast computed for the Jason 2 track 222, the SARAL track 302, the Sentinel-3 track 472 and SYMPHONIE sampled as 1-Hz altimetry.

\begin{tabular}{|l|l|l|l|}
\hline Dataset & SSH drop $(\mathbf{c m})$ & NC width $(\mathbf{k m})$ & $\begin{array}{l}\text { Distance to the coast of } \\
\text { the NC core }(\mathbf{k m})\end{array}$ \\
\hline Jason 2 track 222 & 10.2 & 33 & 27 \\
\hline SYMPHONIE & 6.6 & 27 & 27 \\
\hline SARAL track 302 & 7.1 & 25 & 20 \\
\hline SYMPHONIE & 6.8 & 20 & 12 \\
\hline Sentinel-3 track 472 & 8.2 & 29 & 17 \\
\hline SYMPHONIE & 6.8 & 28 & 17 \\
\hline
\end{tabular}


https://doi.org/10.5194/os-2022-8

Preprint. Discussion started: 21 February 2022

Table 3: Statistics corresponding to the distributions shown on Fig. 8, 9 and 10.

\begin{tabular}{|c|c|c|c|c|}
\hline & Mission & $\begin{array}{l}\text { standard } \\
\text { deviation }\end{array}$ & median & $\begin{array}{l}\text { number of points } \\
>0.25 \mathrm{~m} \mathrm{~s}^{-1} \text { or <- } \\
0.6 \mathrm{~m} \mathrm{~s}^{-1}\end{array}$ \\
\hline \multirow[t]{3}{*}{ model (daily) } & Jason 2 & $0.14(0.14) \mathrm{m} \mathrm{s}^{-1}$ & $-0.17(-0.16) \mathrm{m} \mathrm{s}^{-1}$ & $6(16)$ \\
\hline & SARAL & $0.15(0.14) \mathrm{m} \mathrm{s}^{-1}$ & $-0.16(-0.16) \mathrm{m} \mathrm{s}^{-1}$ & $0(16)$ \\
\hline & Sentinel-3 & $0.13(0.13) \mathrm{m} \mathrm{s}^{-1}$ & $-0.17(-0.16) \mathrm{m} \mathrm{s}^{-1}$ & $0(1)$ \\
\hline \multirow[t]{3}{*}{ raw } & Jason 2 & $0.36 \mathrm{~m} \mathrm{~s}^{-1}$ & $-0.20 \mathrm{~m} \mathrm{~s}^{-1}$ & 342 \\
\hline & SARAL & $0.18 \mathrm{~m} \mathrm{~s}^{-1}$ & $-0.22 \mathrm{~m} \mathrm{~s}^{-1}$ & 7 \\
\hline & Sentinel-3 & $0.23 \mathrm{~m} \mathrm{~s}^{-1}$ & $-0.19 \mathrm{~m} \mathrm{~s}^{-1}$ & 18 \\
\hline \multirow[t]{3}{*}{30 km } & Jason 2 & $0.23 \mathrm{~m} \mathrm{~s}^{-1}$ & $-0.21 \mathrm{~m} \mathrm{~s}^{-1}$ & 104 \\
\hline & SARAL & $0.14 \mathrm{~m} \mathrm{~s}^{-1}$ & $-0.19 \mathrm{~m} \mathrm{~s}^{-1}$ & 1 \\
\hline & Sentinel-3 & $0.17 \mathrm{~m} \mathrm{~s}^{-1}$ & $-0.20 \mathrm{~m} \mathrm{~s}^{-1}$ & 8 \\
\hline \multirow[t]{3}{*}{$40 \mathrm{~km}$} & Jason 2 & $0.19 \mathrm{~m} \mathrm{~s}^{-1}$ & $-0.21 \mathrm{~m} \mathrm{~s}^{-1}$ & 52 \\
\hline & SARAL & $0.13 \mathrm{~m} \mathrm{~s}^{-1}$ & $-0.19 \mathrm{~m} \mathrm{~s}^{-1}$ & 1 \\
\hline & Sentinel-3 & $0.14 \mathrm{~m} \mathrm{~s}^{-1}$ & $-0.20 \mathrm{~m} \mathrm{~s}^{-1}$ & 4 \\
\hline \multirow[t]{3}{*}{50 km } & Jason 2 & $0.16 \mathrm{~m} \mathrm{~s}^{-1}$ & $-0.21 \mathrm{~m} \mathrm{~s}^{-1}$ & 15 \\
\hline & SARAL & $0.11 \mathrm{~m} \mathrm{~s}^{-1}$ & $-0.19 \mathrm{~m} \mathrm{~s}^{-1}$ & 0 \\
\hline & Sentinel-3 & $0.13 \mathrm{~m} \mathrm{~s}^{-1}$ & $-0.20 \mathrm{~m} \mathrm{~s}^{-1}$ & 3 \\
\hline $60 \mathrm{~km}$ & Jason 2 & $0.14 \mathrm{~m} \mathrm{~s}^{-1}$ & $-0.20 \mathrm{~m} \mathrm{~s}^{-1}$ & 9 \\
\hline $70 \mathrm{~km}$ & Jason 2 & $0.12 \mathrm{~m} \mathrm{~s}^{-1}$ & $-0.20 \mathrm{~m} \mathrm{~s}^{-1}$ & 1 \\
\hline
\end{tabular}


https://doi.org/10.5194/os-2022-8

Preprint. Discussion started: 21 February 2022

(c) Author(s) 2022. CC BY 4.0 License.

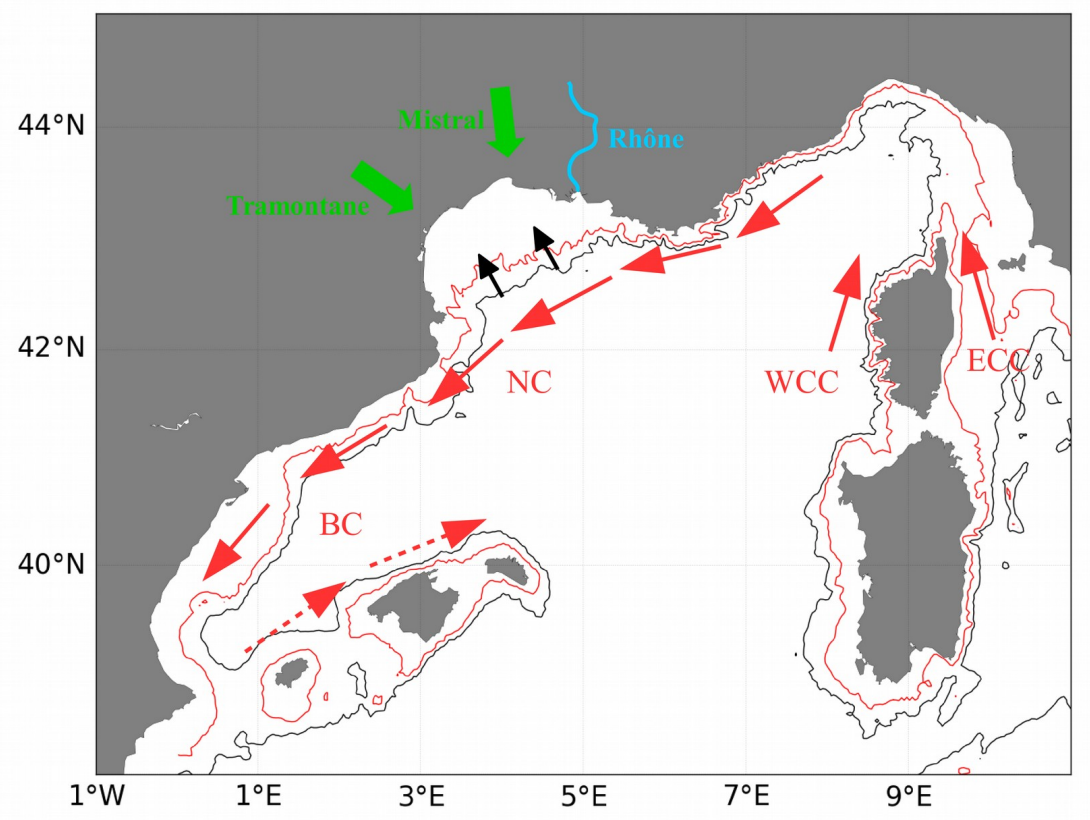

Figure 1: Schematic circulation in the Northwestern Mediterranean Sea. Red arrows indicate the main currents; black arrows indicate the intrusion in the Gulf of Lion. $200 \mathrm{~m}$ (red line) and $1000 \mathrm{~m}$ (black line) isobaths are also shown. 
https://doi.org/10.5194/os-2022-8

Preprint. Discussion started: 21 February 2022

(c) Author(s) 2022. CC BY 4.0 License.
Ocean Science

Discussions

\section{(c) (1)}

(a)

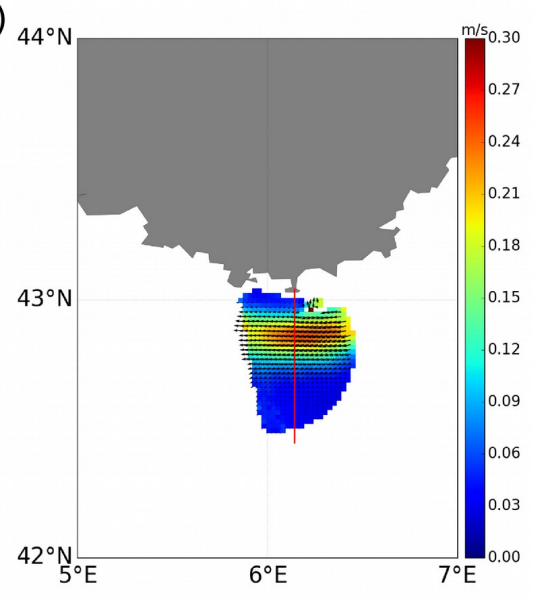

(c)

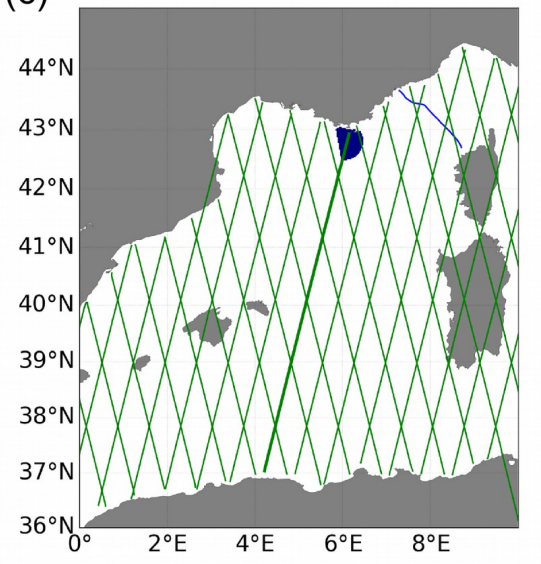

(b)

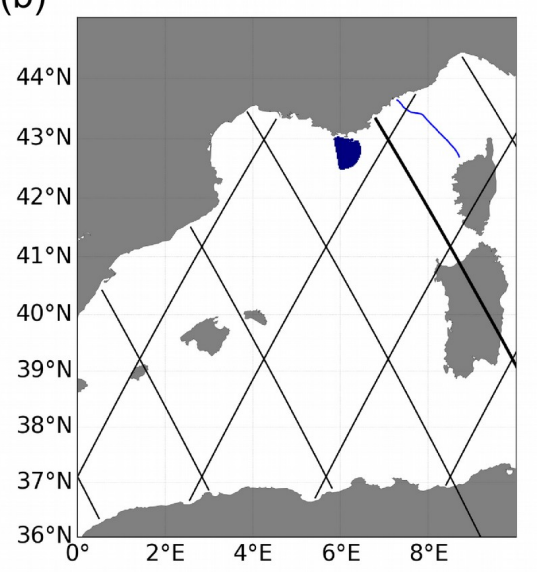

(d)

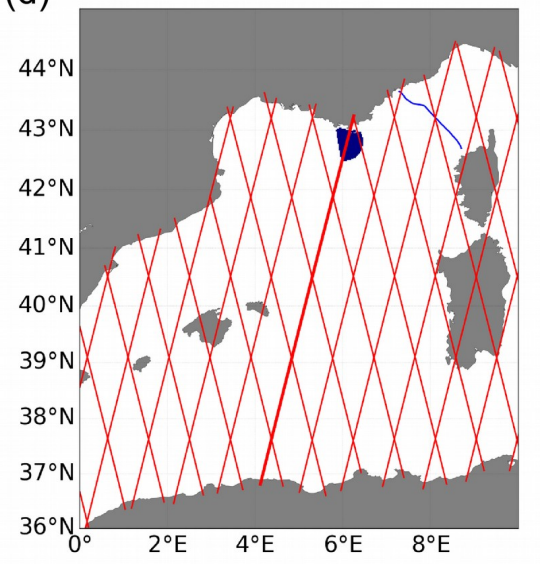

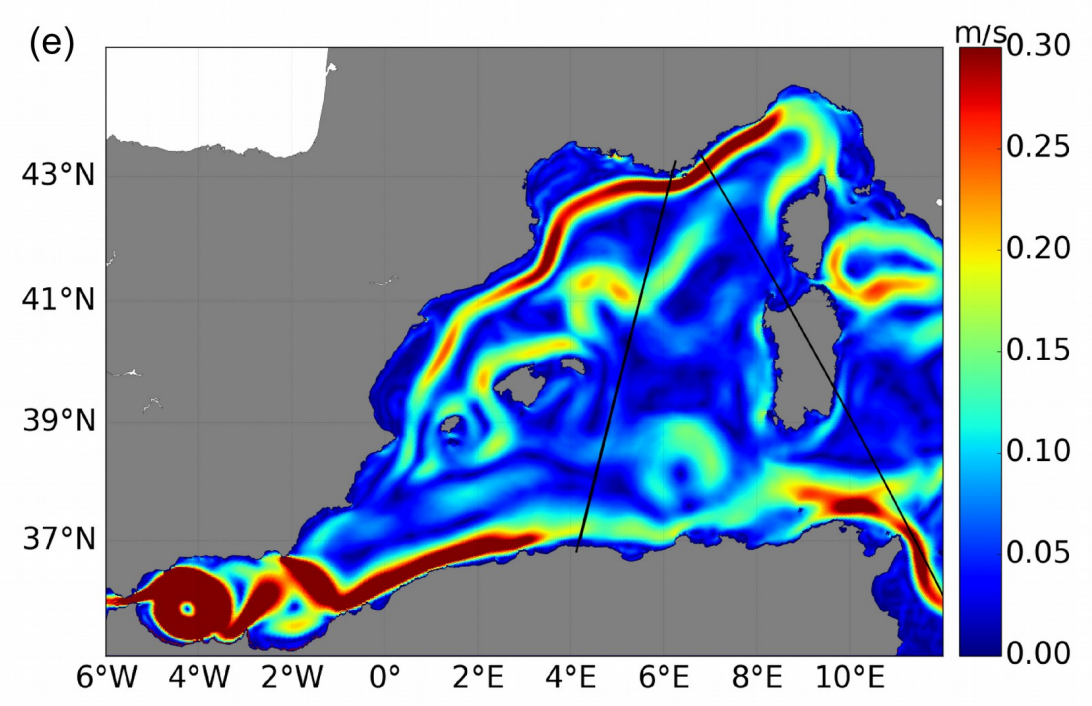


https://doi.org/10.5194/os-2022-8

Preprint. Discussion started: 21 February 2022

(C) Author(s) 2022. CC BY 4.0 License.

Figure 2: Maps illustrating the location of the observations used in this study as well as the spatial model coverage. (a) Amplitude and vectors of mean surface currents from the HF radars

780 near Toulon; the red line shows the transect used in the study. Altimetry tracks in the Western Mediterranean Sea for (b) Jason 2 ; (c) SARAL ; (d) Sentinel-3. For each mission, the tracks used in the study (track 222 for Jason 2 ; track 302 for SARAL; track 472 for Sentinel-3) are indicated in bold. The HF radars region and the gliders transect are represented in blue. (e) Mean surface currents from the SYMPHONIE model for the period 18/05/2011-31/03/2017. The 785 satellite tracks are represented in black. 
https://doi.org/10.5194/os-2022-8

Preprint. Discussion started: 21 February 2022

(c) Author(s) 2022. CC BY 4.0 License.

(a)

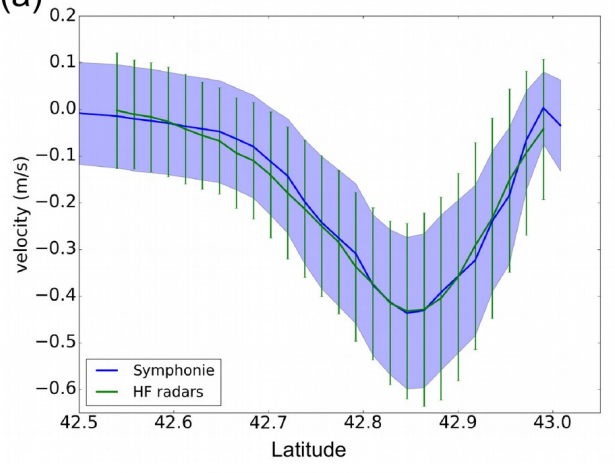

(b)

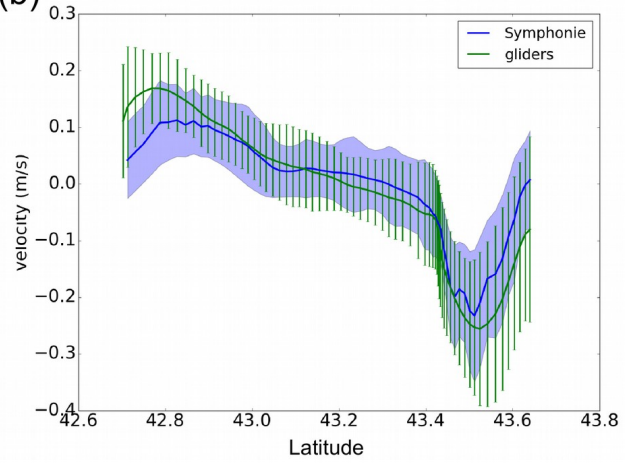

(c)
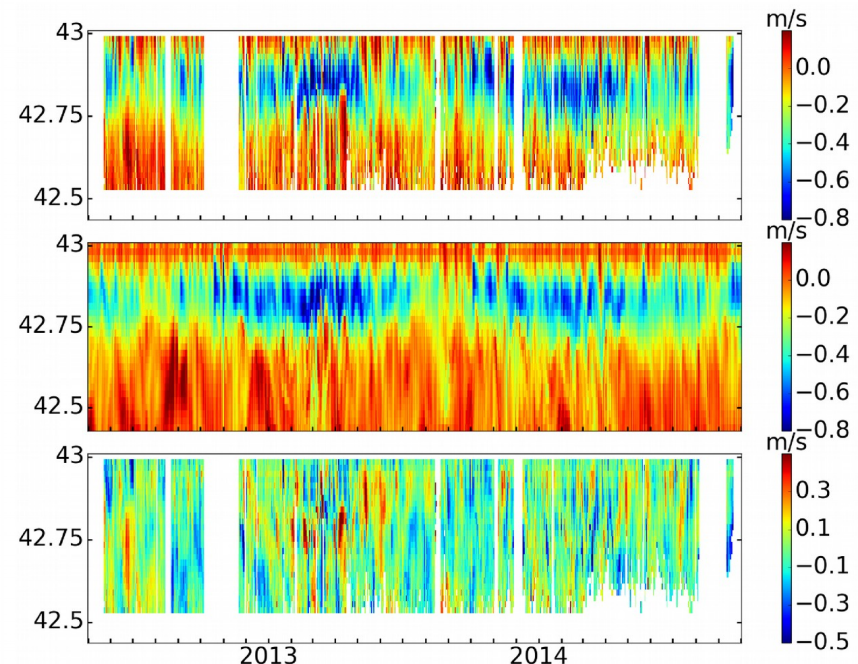

(d)

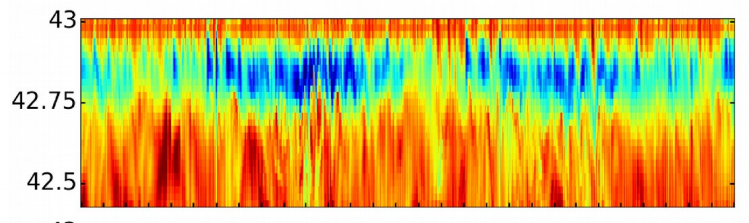

$-0.2$
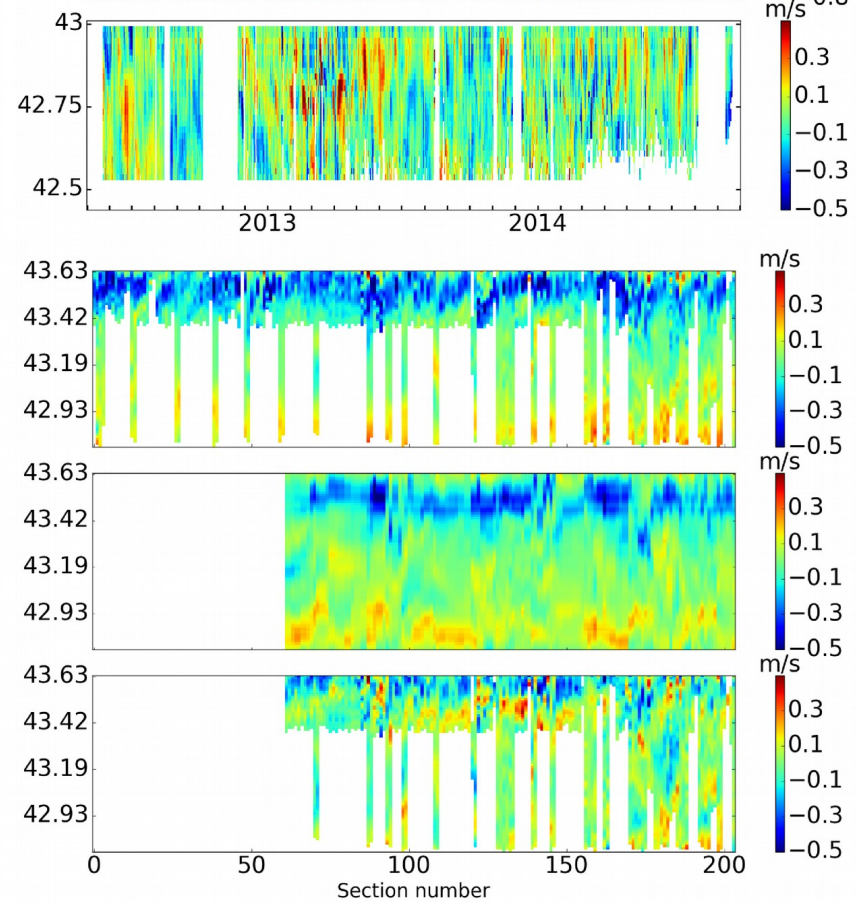
https://doi.org/10.5194/os-2022-8

Preprint. Discussion started: 21 February 2022

(c) Author(s) 2022. CC BY 4.0 License.

Figure 3: Mean zonal current velocities (a) along a meridional section located at $6.14^{\circ} \mathrm{E}$ for the simulation in blue and the HF radars in green ; (b) along the Nice-Calvi line for the simulation

790 in blue and the gliders in green. The blue envelope represents the standard deviation at each point. The distance is referenced to the coast. Time space diagrams of (c) the zonal current component along a meridional section located at $6.14^{\circ} \mathrm{E}$ given by the $\mathrm{HF}$ radars (top panel) and the simulation (middle panel) ; (d) the geostrophic current for the gliders (top panel) and the simulation at the glider temporal resolution (middle panel). Lower panels of (c) and (d) show the differences between the observations and the simulation. 
(a)
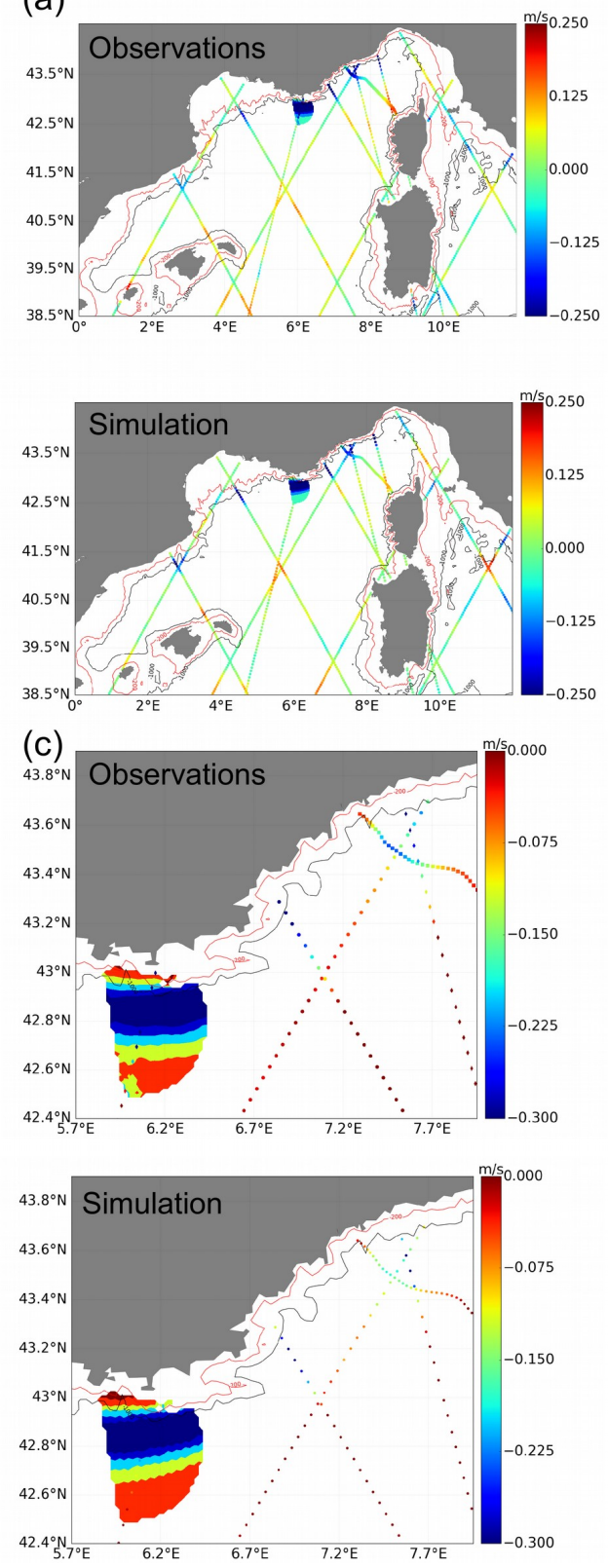

(b)
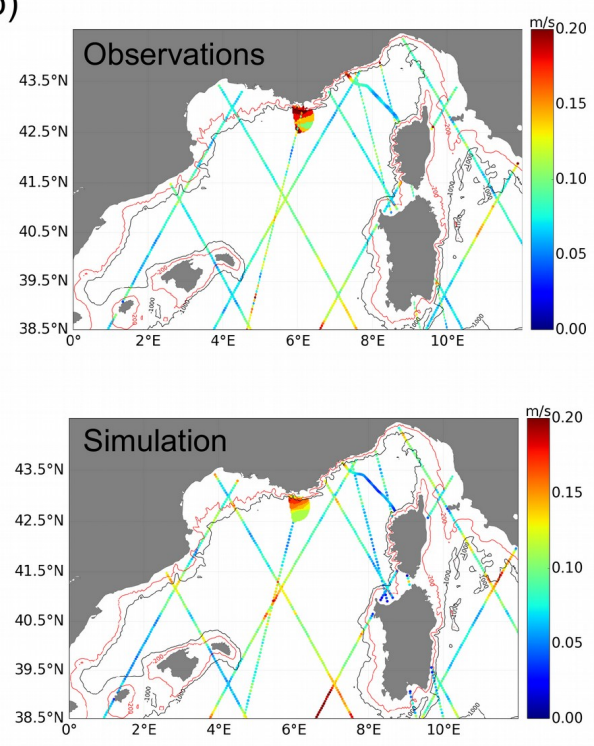

(d)
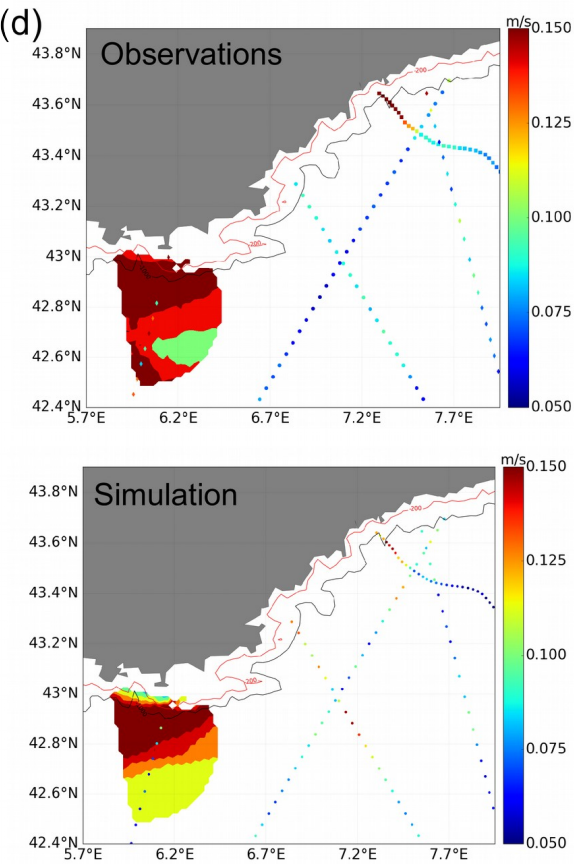

Figure 4 : Maps of the mean current value perpendicular to the tracks derived (a) over the whole region and (c) for a zoomed-in view. (b) and (d) same as (a) and (c) for the standard deviation of currents. The top figure of each panel represents currents from glider, HF radars and altimetry data and the bottom figure from the SYMPHONIE model interpolated at the dates and points of every instrument over the period March 2013-October 2014. $200 \mathrm{~m}$ (red line) and $1000 \mathrm{~m}$ (black line) isobaths are also shown. Top figures are taken from Carret et al. (2019). 
(a)

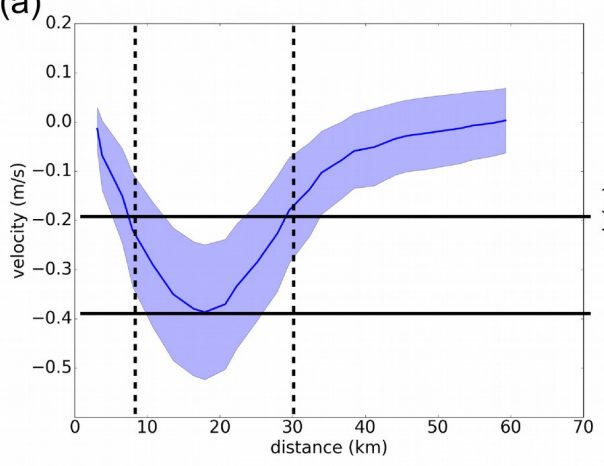

(b)

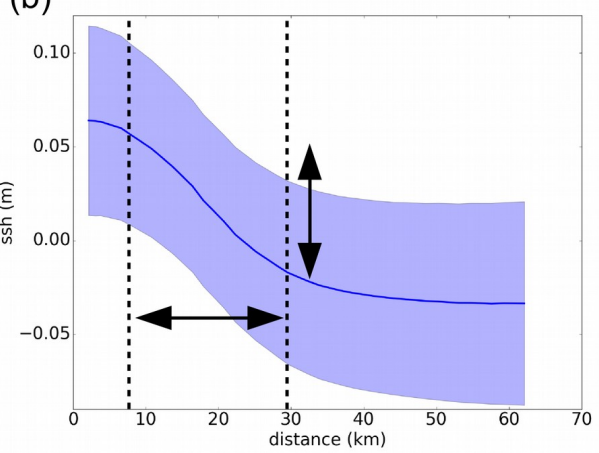

(c)
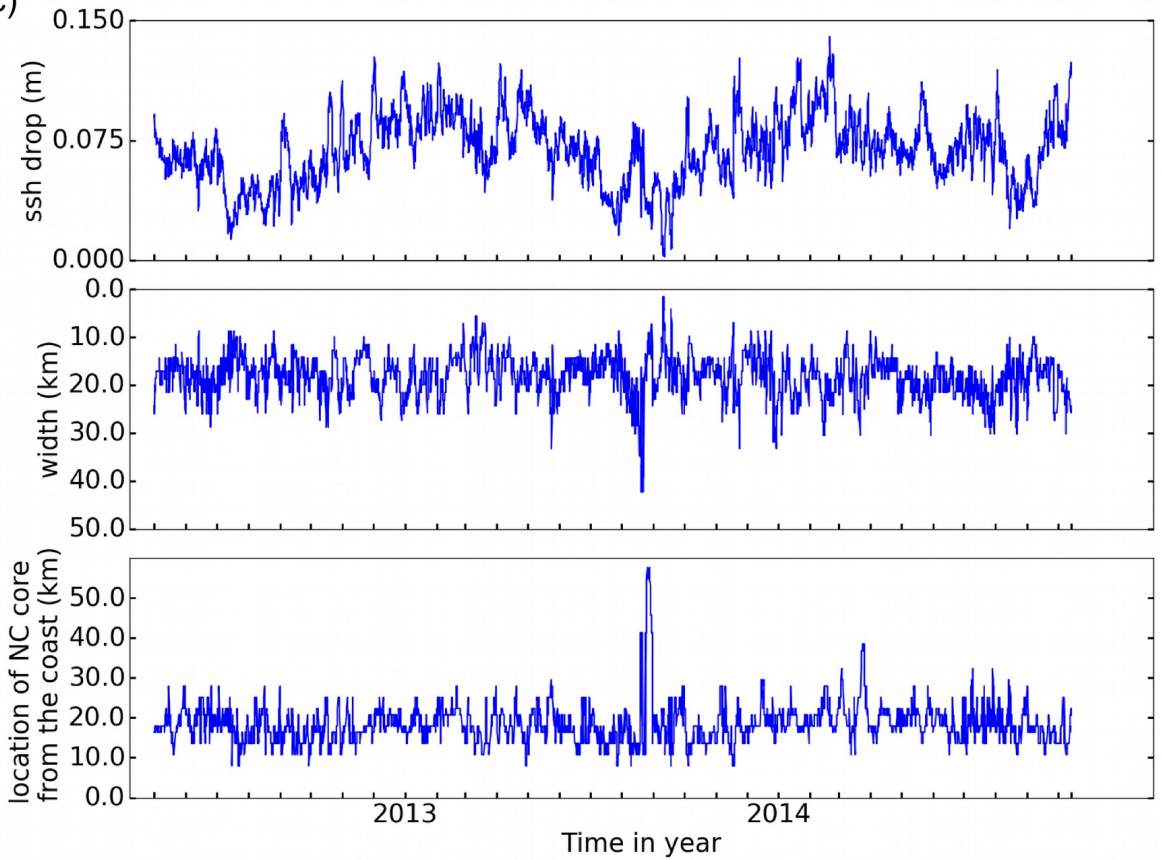

Figure 5: Time averaged (a) current velocities and (b) SSH along a meridional section located at

$6.14^{\circ} \mathrm{E}$ for the SYMPHONIE model. (c) Time series of the SSH drop (in $\mathrm{m}$, upper panel), width (in $\mathrm{km}$, middle panel) of the $\mathrm{NC}$, and location of the $\mathrm{NC}$ core as a function of the distance to the coast (in $\mathrm{km}$, lower panel). The blue envelope in (a) and (b) represent the standard deviation at each point. 
https://doi.org/10.5194/os-2022-8

Preprint. Discussion started: 21 February 2022

(c) Author(s) 2022. CC BY 4.0 License.

(a)

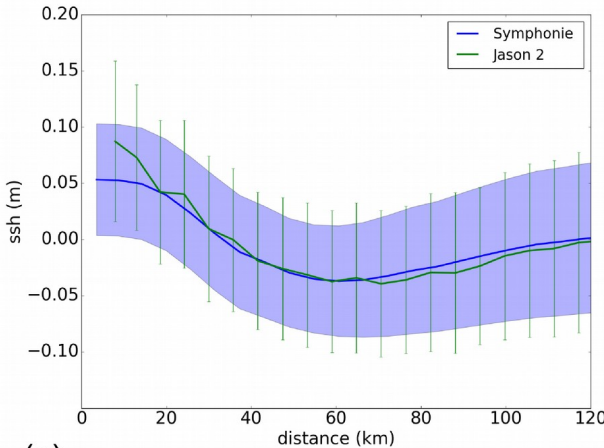

(c)

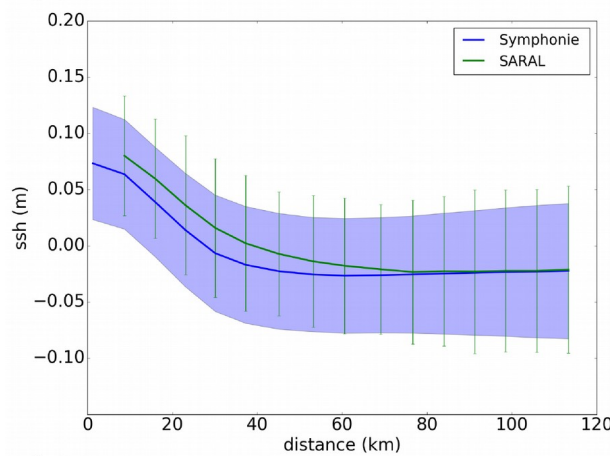

(e)

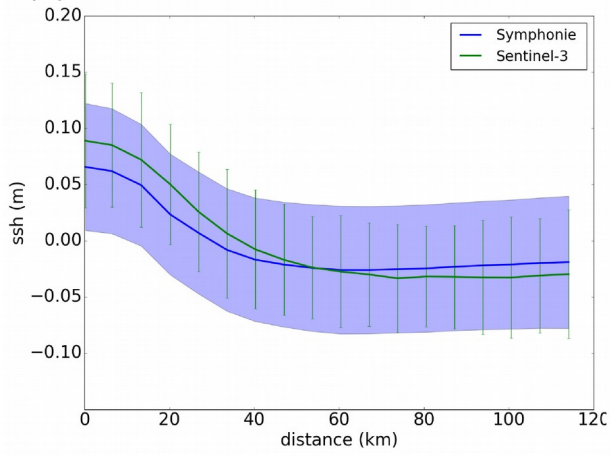

(b)

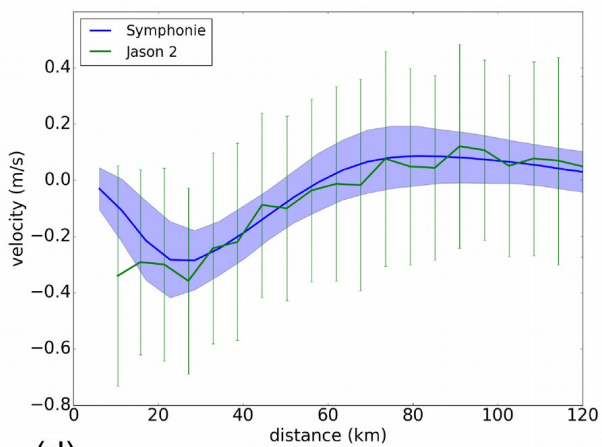

(d)

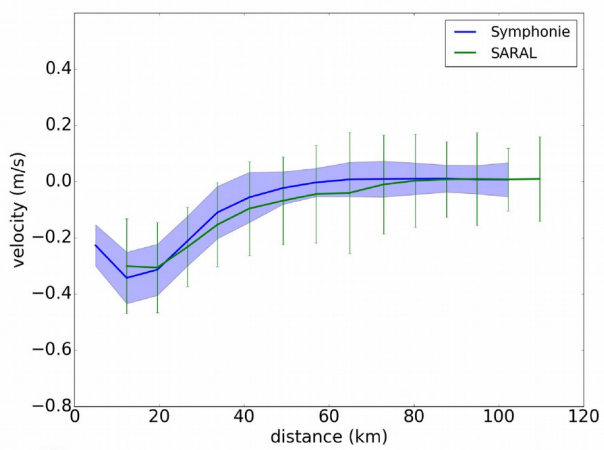

(f)

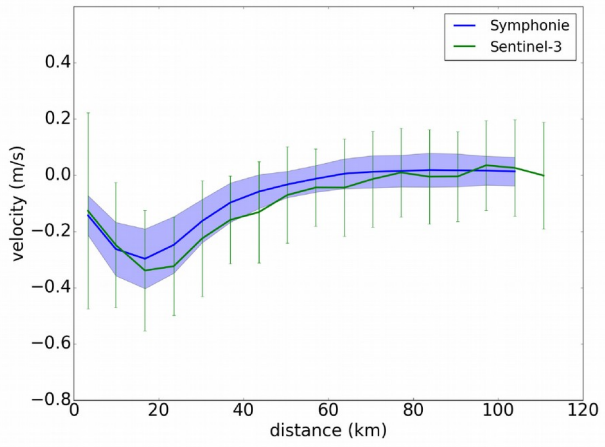

Figure 6: Mean (a), (c), (e) SSH and (b), (d), (f) current velocities along (a), (b) Jason 2 track 222; (c), (d) SARAL track 302; (e), (f) Sentinel-3 track 472 for the model in blue and altimetry raw data in green. The blue envelope and green bars represent the standard deviation at each point. The distance is referenced to the coast. 
https://doi.org/10.5194/os-2022-8

Preprint. Discussion started: 21 February 2022

(c) Author(s) 2022. CC BY 4.0 License.
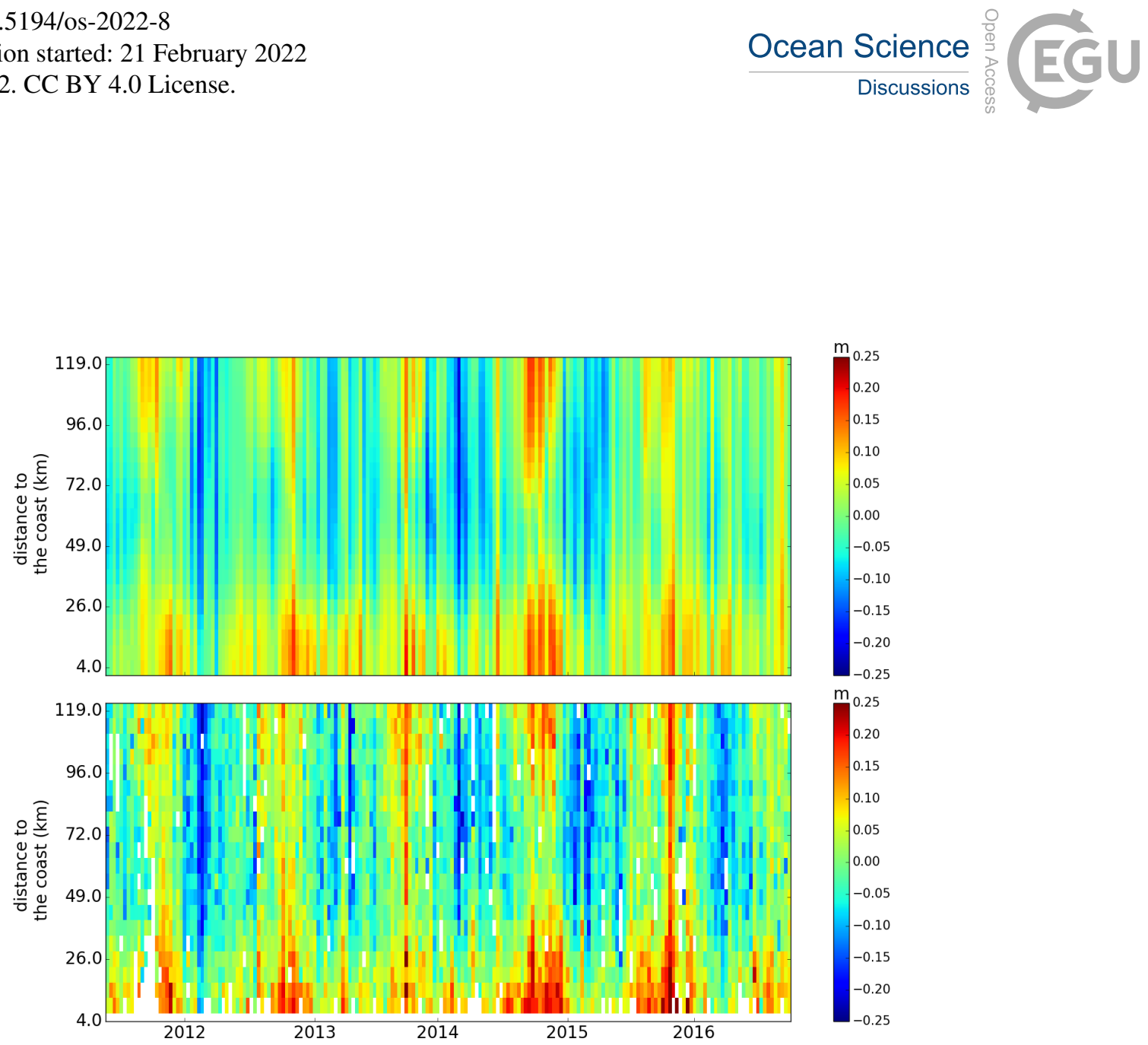

Figure 7: Time space diagrams of SSH along the Jason 2 track 222 for the model (upper panel) and for Jason 2 (lower panel), as a function of the distance to the coast. 
https://doi.org/10.5194/os-2022-8

Preprint. Discussion started: 21 February 2022

(c) Author(s) 2022. CC BY 4.0 License.

(a)

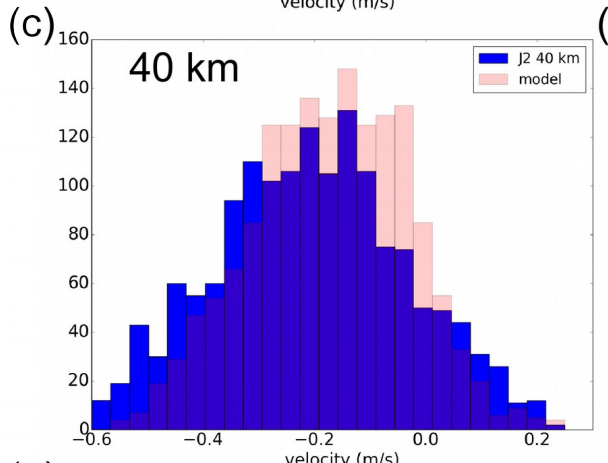

(e)

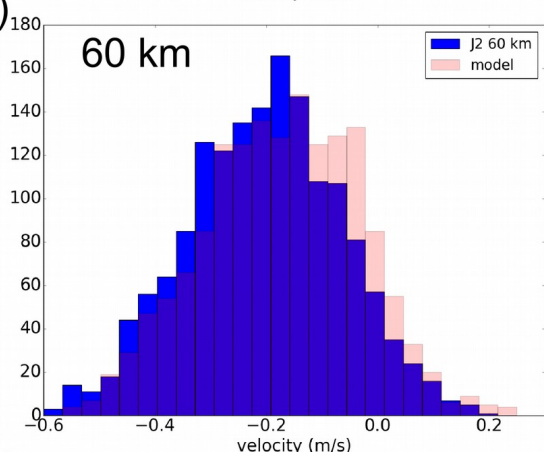

(g)

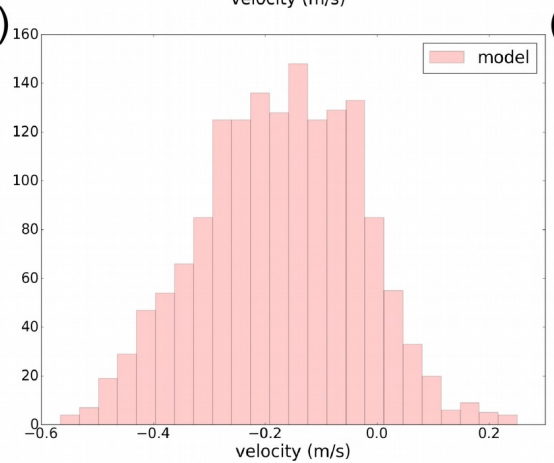

(b)

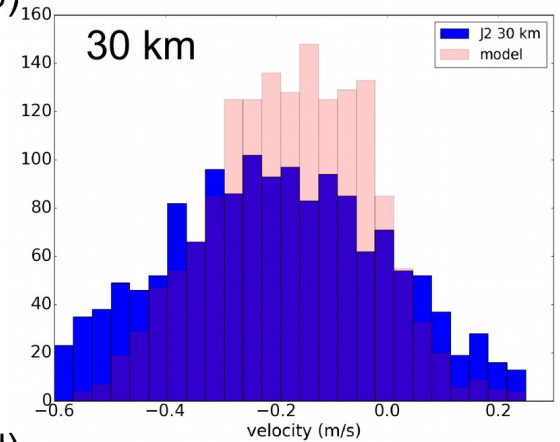

(d)

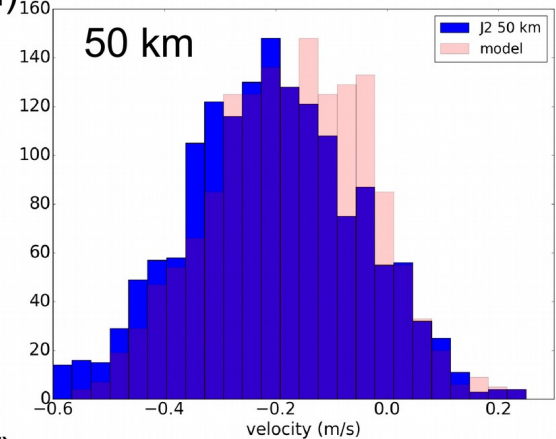

(f)

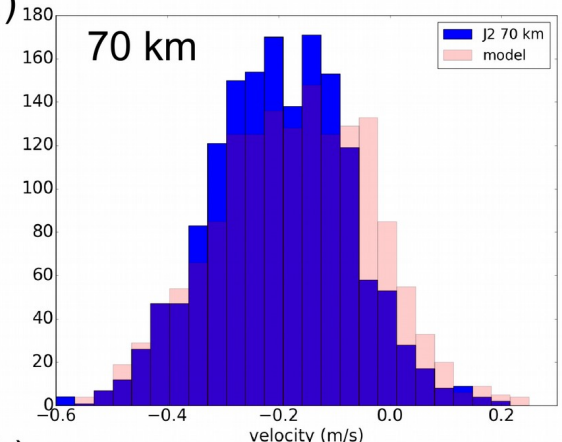

(h)

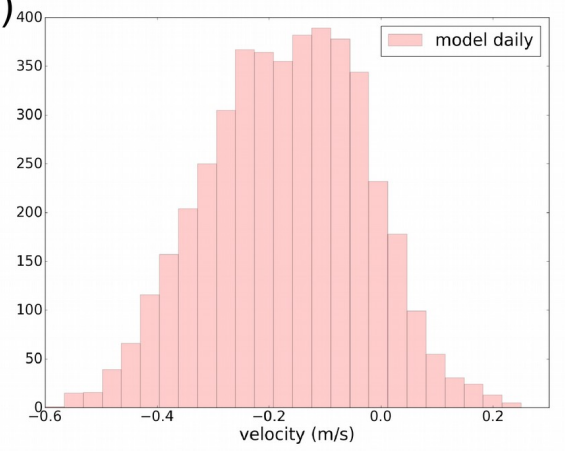


https://doi.org/10.5194/os-2022-8

Preprint. Discussion started: 21 February 2022

(c) Author(s) 2022. CC BY 4.0 License.

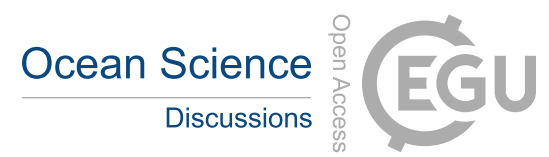

Figure 8: Distribution of the current values along the Jason 2 track 222 and over the first $60 \mathrm{~km}$ to the coast for (a) raw altimetry data and (b),(c),(d),(e),(f) low-pass filtered altimetry data with different cutoff frequencies indicated in the panels. Altimetry distributions (in blue) are superimposed on the corresponding model distribution (in pink). The latter is computed for the Jason 2 temporal resolution (g) and for the model resolution (h) 
https://doi.org/10.5194/os-2022-8

Preprint. Discussion started: 21 February 2022

(c) Author(s) 2022. CC BY 4.0 License.

(a)

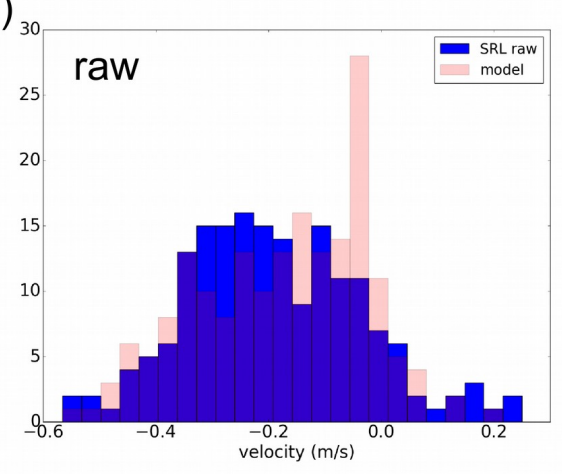

(c)

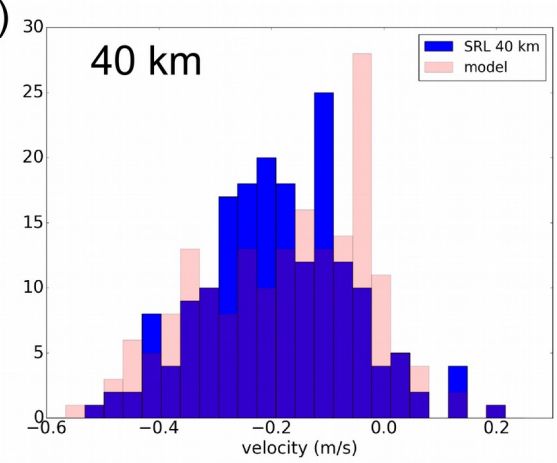

(e)

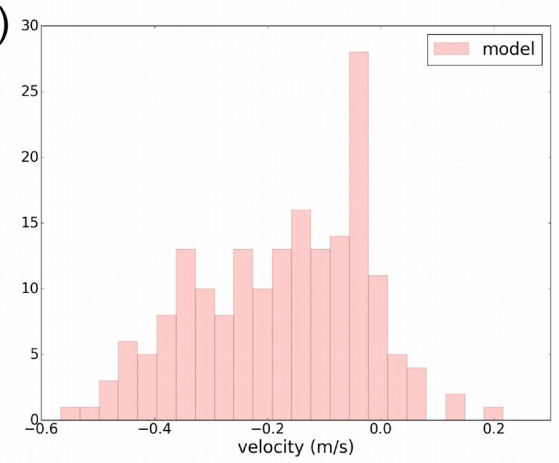

(b)

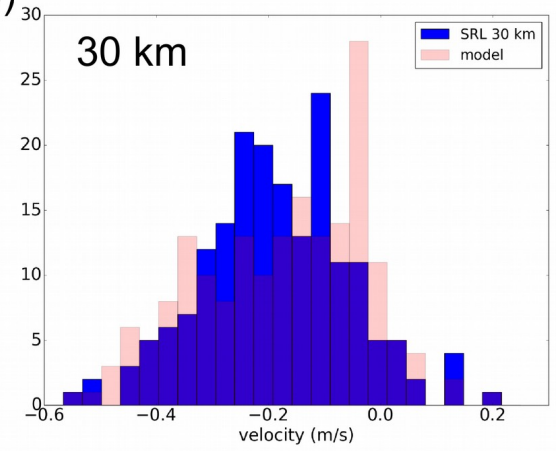

(d)

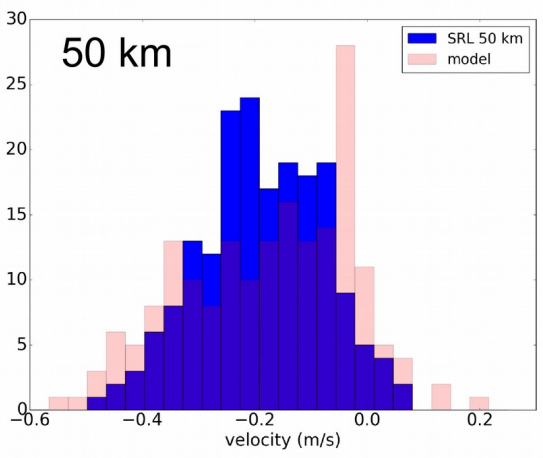

(f)

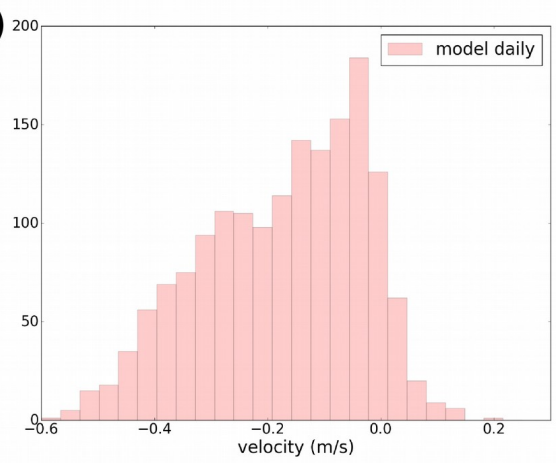

Figure 9: Distribution of the current values along the SARAL track 302 and over the first $60 \mathrm{~km}$ to the coast for (a) raw altimetry data and (b),(c),(d),(e),(f) different filters indicated on each panel. Altimetry distribution (in blue) is superimposed on the corresponding model distribution (in pink). The latter is computed for the SARAL temporal resolution (g) and for the model resolution (h) 
(a)

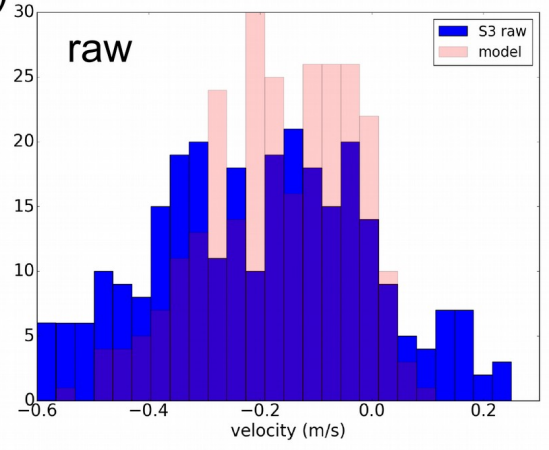

(c)

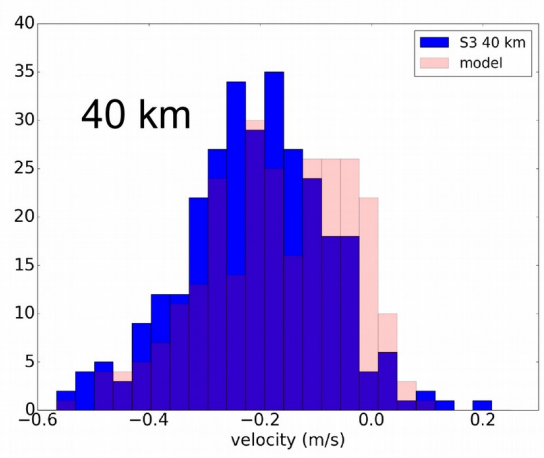

(e)

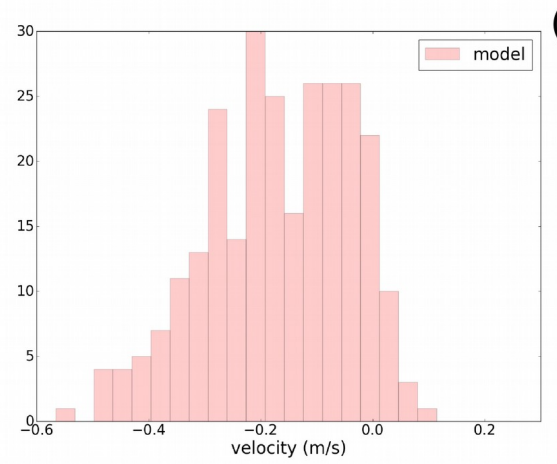

(b)

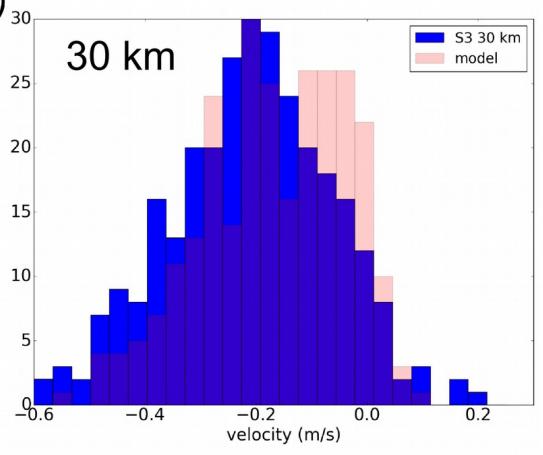

$(d)$

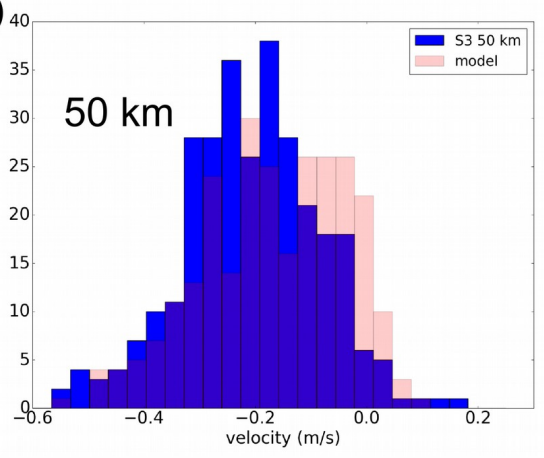

(f)

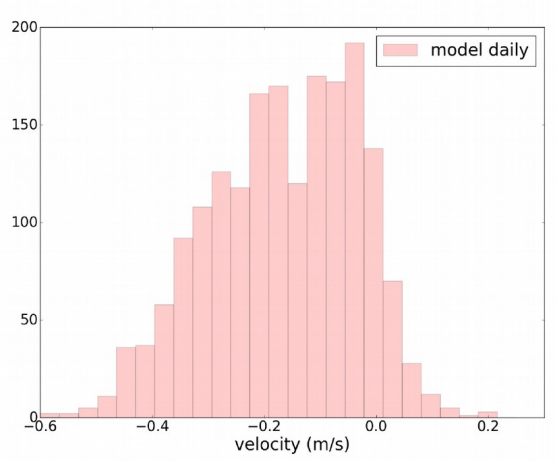

Figure 10: Distribution of the current values along the Sentinel-3 track 472 and over the first 60 $\mathrm{km}$ to the coast for (a) raw altimetry data and (b),(c),(d),(e),(f) different filters (in blue). Altimetry distribution (in blue) is superimposed on the corresponding model distribution (in pink). The latter is computed for the Sentinel-3 temporal resolution (g) and for the model resolution (h) 